\title{
Spatiotemporal variability of Canadian High Arctic glacier surface albedo from MODIS data, 2001-2016
}

\author{
Colleen A. Mortimer and Martin Sharp \\ Department of Earth and Atmospheric Sciences, University of Alberta, Edmonton, T6G 2E3, Canada
}

Correspondence: Colleen A. Mortimer (cmortime@ualberta.ca)

Received: 2 August 2017 - Discussion started: 23 August 2017

Revised: 14 November 2017 - Accepted: 19 January 2018 - Published: 28 February 2018

\begin{abstract}
Inter-annual variations and longer-term trends in the annual mass balance of glaciers in Canada's Queen Elizabeth Islands (QEI) are largely attributable to changes in summer melt. The largest source of melt energy in the QEI in summer is net shortwave radiation, which is modulated by changes in glacier surface albedo. We used measurements from the Moderate Resolution Imaging Spectroradiometer (MODIS) sensors to investigate large-scale spatial patterns, temporal trends, and variability in the summer surface albedo of QEI glaciers from 2001 to 2016. Mean summer blacksky shortwave broadband albedo (BSA) decreased at a rate of $0.029 \pm 0.025 \mathrm{decade}^{-1}$ over that period. Larger reductions in BSA occurred in July $\left(-0.050 \pm 0.031\right.$ decade $\left.^{-1}\right)$. No change in BSA was observed in either June or August. Most of the decrease in BSA, which was greatest at lower elevations around the margins of the ice masses, occurred between 2007 and 2012, when mean summer BSA was anomalously low. The first principal component of the 16-year record of mean summer BSA was well correlated with the mean summer North Atlantic Oscillation index, except in 2006, 2010, and 2016, when the mean summer BSA appears to have been dominated by the August BSA. During the period 2001-2016, the mean summer land surface temperature (LST) over the QEI glaciers and ice caps increased by $0.049 \pm 0.038^{\circ} \mathrm{C} \mathrm{yr}^{-1}$, and the BSA record was negatively correlated $(r:-0.86)$ with the LST record, indicative of a positive ice-albedo feedback that would increase rates of mass loss from the QEI glaciers.
\end{abstract}

\section{Introduction}

The area of glaciers and ice caps in the Queen Elizabeth Islands (QEI, Fig. 1), Arctic Canada, in 2000 was $\sim 104000 \mathrm{~km}^{2}$ (Arendt et al., 2012). From 2000 to 2015, the summer mean surface temperature of glaciers in this region increased at a rate of $0.06 \pm 0.04{ }^{\circ} \mathrm{C} \mathrm{yr}^{-1}$, and summer mean air temperatures from 2005 to 2012 were $>1.0^{\circ} \mathrm{C}$ warmer than the 1948-2015 mean (Mortimer et al., 2016). QEI summer mean air and glacier surface temperatures are strongly correlated with the annual and summer glacier mass balances, which have become increasingly negative since at least 2003 (Gardner et al., 2013; Lenaerts et al., 2013; Wolken et al., 2016). Inter-annual variations and longer-term trends in annual glacier mass balance in the QEI are dominated by changes in summer melt (Koerner, 2005), and net shortwave radiation is the largest source of melt energy on the QEI ice caps (Gascon et al., 2013). Variability in net shortwave radiation, in turn, is strongly modulated by changes in the surface albedo (van den Broeke et al., 2011; Tedesco et al., 2016), the ratio of reflected to incoming solar radiation.

The high albedo of fresh snow declines naturally over time due to settling and grain growth (Warren, 1982). This initial decrease in albedo raises the shortwave energy absorption, leading to warming and/or melt, and a further lowering of the surface albedo. Warmer temperatures and increased snowpack water content further accelerate grain growth, causing a more rapid albedo decline that enhances surface warming and/or melt (Wiscombe and Warren, 1980; Colbeck, 1982). A positive snow/ice albedo feedback has been linked to accelerating high-latitude warming and is increasingly recognized as an important factor in explaining recent increases in 
rates of mass loss from the Greenland Ice Sheet (e.g. Tedesco et al., 2016), which lies immediately to the east of the QEI.

On glaciers and ice caps, surface warming and increased melt in summer can lead to earlier and more widespread removal of the previous winter's snowpack, and earlier and more prolonged exposure of underlying low-albedo glacier ice. Albedo decreases can also be caused by aerosol deposition (Warren and Wiscombe, 1980); biological activity on glacier surfaces (Fountain et al., 2004); and the release of impurities contained within melting snow and ice, which become concentrated at the snow/ice surface (Clarke and Noone, 1985; Conway et al., 1996; Flanner et al., 2007; Doherty et al., 2010). Given the observed increases in air and glacier surface temperatures across the QEI (Mortimer et al., 2016) we anticipate a reduction in the surface albedo in this region, unless warming has also been accompanied by an increase in solid precipitation (Vincent et al., 2015) that is large enough to raise the surface albedo (e.g. Box et al., 2012). The expected albedo reduction has, however, yet to be documented or quantified.

Decadal-scale declines in the surface albedo of the Greenland Ice Sheet have been simulated using regional climate models and documented using remote sensing data validated by in situ measurements (e.g. Stroeve et al., 2005, 2013; Box et al., 2012, 2017; Alexander et al., 2014; Tedesco et al., 2016; Casey et al., 2017). Global assessments of land surface albedo (e.g. He et al., 2014) have included the QEI, but these analyses were extremely broad in nature and the detailed spatial pattern of glacier albedo change and its variation over time are unknown. Between 2000 and 2015, increases in QEI summer $700 \mathrm{hPa}$ air temperatures derived from the NCEP/NCAR Reanalysis 1 (R1) (Kalnay et al., 1996) and glacier surface temperatures from the Moderate Resolution Imaging Spectroradiometer (MODIS) were greatest in the north and west of the QEI (Sharp et al., 2011; Mortimer et al., 2016). We do not know whether there is a similar spatial pattern in the albedo record.

Field-based measurements provide information about the surface albedo at specific locations, but there are no longterm spatially distributed in situ records of the surface radiation budget of glaciers and ice caps in the QEI. Remote sensing methods enable monitoring of the surface albedo and its spatial and temporal variability at the scale of both individual ice caps and the regional glacier cover. Here, we use measurements of surface albedo from the MODIS sensors to present the first near-complete picture of variations in the summer surface albedo of QEI glaciers and ice caps from 2001 to 2016 . We characterize the spatial and temporal variability in summer albedo, and quantify the rate of albedo change across the QEI.

\section{Data and methods}

\subsection{MCD43A3 data}

Observations from the MODIS sensors, aboard the Terra (2000 to present) and Aqua (2002 to present) satellites (Barnes et al., 1998), are used to assess the spatial and temporal evolution of the surface albedo over the QEI glaciers and ice caps in summer (June-August). We use the MODIS/Terra and Aqua BRDF/Albedo Daily L3 Global $500 \mathrm{~m}$ Collection 6 (C6) product (MCD43A3; Schaaf and Wang, 2015), which provides both white-sky (bi-hemispherical reflectance under isotropic conditions) and black-sky (directional hemispherical reflectance) shortwave broadband surface albedo (Schaaf et al., 2011; https://www.umb.edu/spectralmass/terra_aqua_ modis/v006, and references therein). MCD43A3 albedo is calculated daily for local solar noon using atmospherically corrected surface reflectance measurements made by sensors on both the Terra and Aqua satellites over a 16 day period that is centred on the ninth day of each 16 day moving window (https://www.umb.edu/spectralmass/terra_aqua_ modis/v006). A semi-empirical bidirectional reflectance distribution function (BRDF) model, which describes the surface scattering/reflectance of a target as a function of illumination, is used to estimate surface albedo from directional surface reflectance information recorded by the MODIS sensors (Schaaf et al., 2002, 2011; Jin et al., 2003; Salomon et al., 2006). MCD43A3 white- and black-sky albedos are estimated from Level 2G-lite surface reflectances (MOD/MYD 09 ) for seven visible and near-infrared bands (spanning 0.4$2.4 \mu \mathrm{m})$ and three broadbands (shortwave $(0.3-5.0 \mu \mathrm{m})$, visible $(0.3-0.7 \mu \mathrm{m})$ and near infrared $(0.7-5.0 \mu \mathrm{m}))$ in one of two ways.

If sufficient ( $>7)$ multi-date cloud-free observations with adequate angular sampling to fully characterize the viewing/illumination geometry are acquired during a 16 day period, a high-quality full inversion is run using a semiempirical RossThick LiSparse Reciprocal (RTSLR) kerneldriven BRDF model (Wanner et al., 1997; Lucht et al., 2000; Schaaf et al., 2002, 2011). If insufficient observations (< 7) are available, then a lower-quality magnitude inversion, which relies on a priori knowledge to scale an archetypal BRDF, is used to estimate the surface albedo (Strugnell and Lucht, 2001; Schaaf et al., 2002; Jin et al., 2003; Liu et al., 2009). Data quality flags, provided in the MCD43A2 data quality assessment product, indicate whether albedo values (for each pixel) were obtained using the full or magnitude inversion. Since this study aims to generate an initial assessment of the spatiotemporal variability of the surface albedo of glaciers and ice caps in the QEI with good spatial coverage, both full and magnitude inversion data are used. Although magnitude inversions produce lower-quality albedo estimates than the full-inversion method, previous work using MODIS C5 data showed that the magnitude inversion data provide a good representation of the seasonal and spa- 


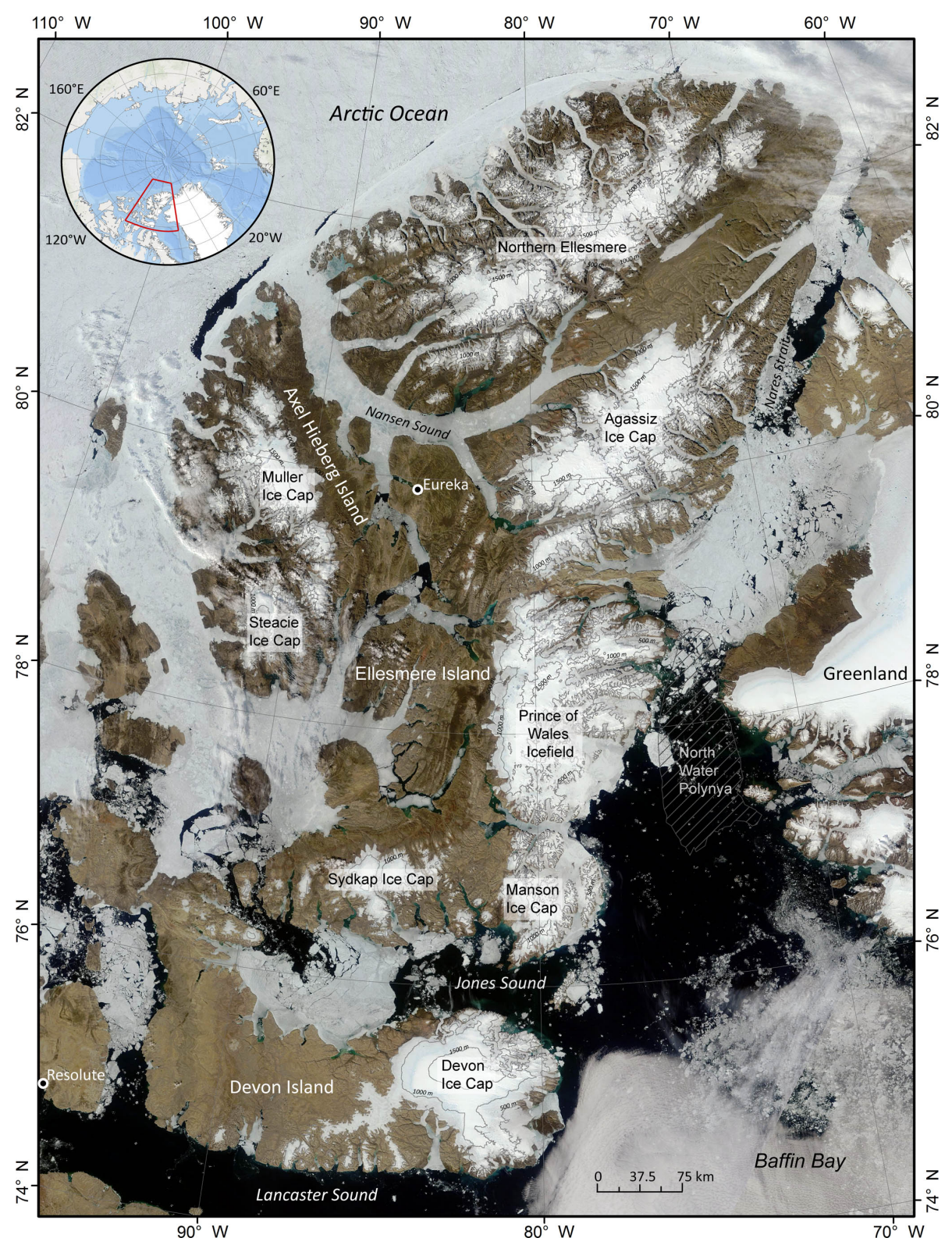

Figure 1. Glaciated regions of the Queen Elizabeth Islands (QEI). Background image: MODIS, 4 July 2011. Inset: red polygon shows location of the QEI, Arctic Canada.

tial patterns of glacier surface albedo (Schaaf et al., 2011; Stroeve et al., 2013). To our knowledge, no recent research comparing the magnitude and full inversion retrievals over glaciers and ice caps has been published for the MCD43A3 C6 data. Comparison of the MODIS C5 and C6 full-inversion albedo data from the Greenland Ice Sheet confirmed many of the broad spatial patterns in surface albedo identified in the C5 data, but the magnitude of the C6 albedo change was much smaller (Casey et al., 2017).

\subsubsection{MODIS sensor degradation}

The MODIS sensors are currently operating well beyond their expected (productive) 6-year lifetimes (Barnes et al., 1998; Justice, 1998), and the detectors are degrading (Xiong et al., 2001). For both the MODIS Terra and Aqua sensors, instruments were calibrated pre-launch (radiometric, spatial, specular calibration) (Gunther et al., 1996). On-orbit calibration procedures were included to monitor the sensor degradation that is expected as the instruments are exposed to solar radiation (Gunther et al., 1996). For the reflective solar bands $(0.41-2.2 \mu \mathrm{m})$ the onboard calibration system in- 
cludes a solar diffuser (SD) calibrated using the solar diffuser stability monitor (SDSM) (Gunther et al., 1998). Lunar and Earth view observations (for select desert sites) are also used to assess radiometric stability (Sun et al., 2003). Even so, long-term scan-mirror- and wavelength-dependent degradation, which are not sufficiently accounted for by the onboard calibrators (SD/SDSM), have been observed (Xiong et al., 2001; Lyapustin et al., 2014, and references therein). Calibration degradation effects, which are largely confined to the MODIS Terra sensor, are greatest in the blue band (B3) and decrease with increasing wavelength (Xiong and Barnes, 2006). An anomaly in the SD door operation (3 May 2003) and a decision to leave the door permanently open, exposing the SD to additional solar radiation, resulted in degradation of the SD on the MODIS Terra sensor that was faster than had originally been anticipated and than that observed for the MODIS Aqua sensor (Xiong et al., 2005). Differences in the response vs. scan angle (RVS) for the two side mirrors were also characterized pre-launch (Barnes et al., 1998). The RVS is important because it describes the scan mirror's response to different angles of incidence (AOI; for each band, detector, and mirror side) (Sun et al., 2014). However, for the MODIS Terra sensor, following an overheating incident during pre-launch calibration, the RVS was not re-characterized, and the exact pre-launch RVS characteristics are not known (Pan et al., 2007; Sun et al., 2014, and references therein). These issues have resulted in the performance of the MODIS Terra sensor being poorer than that of the MODIS Aqua sensor.

As a normal part of the operational procedure, the MODIS Characterization Support Team (http://mcst.gsfc.nasa.gov) periodically updates the calibration algorithms and approaches, during which time the entire Level 1B (L1B) record (calibrated top-of-the-atmosphere (TOA) radiances) is re-processed to reflect improved understanding and characterization of changes to the instruments. Even so, nonphysical trends in MODIS Terra data products, which result from calibration drift, have been observed and are well documented (e.g. Xiong et al., 2001; Xiong and Barnes, 2006; Franz et al., 2008; Kwiatkowski et al., 2008; Wang et al., 2012; Lyapustin et al., 2014, and references therein). The latest revision occurred with the $\mathrm{C} 6$ data and includes on-orbit calibration procedures to mitigate long-term calibration drift, particularly at the shorter wavelengths (Wenny et al., 2010; Toller et al., 2013; Lyapustin et al., 2014; Sun et al., 2014). The C6 dataset uses the onboard calibrators (e.g. SD/SDSM) and the mirror side ratios from lunar standard and Earth view observations (Toller et al., 2013; Sun et al., 2014). The C6 revision also includes an additional approach, aimed primarily at the short-wavelength bands, that uses observations of desert sites (pseudo-invariant targets) to derive instrument calibration coefficients and RVS at multiple AOI (instead of the two AOI provided by the SD and lunar standard) (Toller et al., 2013; Sun et al., 2014). Although this vicarious approach is less accurate than the one that uses the mirror side ratios calibrated using a lunar standard, it has been found to provide a significant improvement to the L1B radiance measurements relative to the C5 data, prior to $\sim 2013$ (Toller et al., 2013; Lyapustin et al., 2014). Updated L1B C6 radiances can be up to several percent higher than the C5 values (e.g. Band 3 and for most recent period $~ 2013$ onward) (Toller et al., 2013; Lyapustin et al., 2014; Casey et al., 2017). However, evaluation of the L1B C6 Band $3(0.46-0.48 \mu \mathrm{m})$ radiance over a desert site (Libya 4 ) identified residual errors (decadal trends on the order of several tenths of $1 \%$; Lyapustin et al. (2014)) that are within the product's stated accuracy (2\% in absolute reflectance units for the reflective solar bands) (Barnes et al., 1998; Justice et al., 1998). The impact of the C6 updates on higher-level MODIS science products is difficult to quantify because the corrections are dependent on time, mirror side, angle, and detector (Toller et al., 2013; Lyapustin et al., 2014; Sun et al., 2014). In addition, the $\mathrm{C} 6$ revision includes updates to algorithms (in addition to the calibration updates) used in the derivation of specific higher-level products (https://www.umb.edu/ spectralmass/terra_aqua_modis/v006 outlines changes made to the MCD43A3 C6 data product). Important for the current study, however, is that recent analysis of surface albedo over the Greenland Ice Sheet, immediately to the east of the QEI, using MODIS C6 data (including the MCD43A3 product used in this study) identified statistically significant albedo declines over the wet snow zone (Casey et al., 2017). For the most part, these declines are thought to be physically real (Casey et al., 2017), which gives us confidence in the albedo trends presented here. There are no long-term, spatially distributed, in situ albedo records from the glaciers and ice caps in the QEI, so a comparison between the MCD43A3 records and ground observations is not possible. This is both a motivation for and a limitation of the current study.

Furthermore, the MCD43A3 data used here were produced only under clear-sky conditions (Hall et al., 2002, 2012). A conservative cloud mask is applied to remove observations made when clouds are detected (Ackerman et al., 1998). The resulting data gaps may introduce variability in the albedo record that is not representative of true physical change. Despite this, the MCD43A3 albedo product has been found to provide a reasonable representation of the seasonal albedo cycle over glaciers and ice caps (e.g. Stroeve et al., 2006). Hence, in the absence of long-term ground measurements of glacier surface albedo in the QEI, we made the assumption that this is also the case in the QEI.

\subsubsection{MCD43A3 data processing}

Summer (1-2 June (day 152) to 30-31 August (day 243)) MODIS MCD43A3 and MCD43A2 C6 (Schaaf and Wang, 2015) data for MODIS tiles h17v00, h16v00, h16v01, and h15v01 for the period 2001-2016 were obtained from the NASA/USGS Land Processes Distributed Active Archive Center (http://lpdaac.usgs.gov/, accessed November 2016). 
Daytime clear-sky white- and black-sky shortwave broadband data (MCD43A3) and accompanying quality assessment information (MCD43A2) were extracted from the hierarchical data format files and re-projected from the standard MODIS sinusoidal projection to a North America Albers equal-area projection, WGS 84 datum, $500 \mathrm{~m}$ resolution, using the MODIS re-projection tool version 4.1 (https: //lpdaac.usgs.gov/tools/modis_reprojection_tool). The maximum summer (June-August) solar zenith angle over our study area $\left(74^{\circ}\right)$ was below the product's stated accuracy ( $<75^{\circ}$; Vermote et al., 2011; Wang et al., 2012), so no additional filtering was performed to remove data with high solar zenith angles.

The white- and black-sky albedos (representing completely diffuse and completely direct illumination, respectively) represent extreme estimates of the actual (blue-sky) bi-hemispheric surface albedo. To avoid redundancy, only results for the black-sky albedo (BSA) (which are fully consistent with those obtained using the white-sky albedo (WSA)) are presented here. The BSA was selected because our analysis focuses on albedo retrieved under clear-sky conditions. This approach is consistent with previous work using MCD43A3 data (e.g. Alexander et al., 2014; Tedesco et al., 2016; Casey et al., 2017).

\subsection{MODIS LST (MOD11A2)}

Warmer surface temperatures increase the rates of grain metamorphism and snowmelt, resulting in larger snow grains which have a lower albedo than those of fresh snow (Wiscombe and Warren, 1980; Colbeck, 1982) (Sect. 1). Air and surface temperatures also affect the timing of removal of the seasonal snowpack, which exposes lower-albedo firn or glacier ice. Additionally, the melt of glacier ice releases impurities that have a low albedo and thus change the surface albedo of both ice and snow (e.g. Clarke and Noone, 1985; Doherty et al., 2010) (Sect. 1). As such, analysis of the glacier surface temperature and comparison of these data with the albedo record is included to help understand the observed spatiotemporal patterns of glacier albedo change in the QEI.

We use the Eight-Day L3 Global Land Surface Temperature and Emissivity product (MOD11A2) C6, which has been found to be a reasonable proxy for the duration and/or intensity of summer melting in the QEI (Sharp et al., 2011; Mortimer et al., 2016), to investigate the relationship between glacier surface temperature and albedo. Only the "daytime" land surface temperature (LST) data, generated with the day/night algorithm of Wan and Li (1997), is evaluated here. This is consistent with previous work in this region (e.g. Sharp et al., 2011; Mortimer et al., 2016). MOD11A2 daytime LSTs are computed from MODIS channels $31(11 \mu \mathrm{m})$ and $32(12 \mu \mathrm{m})$ using a "split-window" technique and all available daytime clear-sky scenes from the Terra satellite, for sequential 8-day periods (Wan et al., 2002). These data have a spatial resolution of $1 \mathrm{~km}$ and nominal product accuracy of $\pm 1{ }^{\circ} \mathrm{C}$, but the accuracy over snow and ice surfaces can be as low as $\pm 2{ }^{\circ} \mathrm{C}$ (Hall et al., 2008a; Koenig and Hall, 2010). The LST analyses presented here are an update of those presented by Mortimer et al. (2016), which used MODIS C5 data. The two analyses also differ in the time period used (we use 2001-2016 instead of 2000-2015 to coincide with the BSA analysis). Pixels for which the average LST error (QC_Day LST error flag) exceeded $2{ }^{\circ} \mathrm{C}$ were removed from the analysis, and any remaining pixels having a temperature $>0{ }^{\circ} \mathrm{C}$ were assigned a temperature of $0^{\circ} \mathrm{C}$ (Mortimer et al., 2016). Uncertainties in trends derived from the MOD11A2 LST data arise mainly from cloud contamination (Box et al., 2012; Hall et al., 2012) and the removal of observations for periods when clouds are detected (Ackerman et al., 1998; Hall et al., 2008b). Variability in the number of clear-sky days within each observation period and from one year to the next was not found to introduce significant variability in the MODIS-derived LST relative to the true near-surface air temperature in the QEI (see Mortimer et al., 2016). MOD11A2 C6 data were downloaded from https://lpdaac.usgs.gov/ (accessed September-October 2017) and re-projected to a North America Albers equal-area projection, WGS84 datum, $1 \mathrm{~km}$ resolution.

\subsection{Mean summer BSA and LST}

Annual precipitation in the QEI is low $\left(<400 \mathrm{~mm} \mathrm{yr}^{-1}\right)$ and varies little from one year to the next; in contrast, the annual temperature range is large $\left(>40^{\circ} \mathrm{C}\right)$ (Braithwaite, 2005). Inter-annual variability in QEI annual mass balance is dominated by changes in the summer mass balance (Koerner, 2005), which, in turn, is strongly correlated with summer air temperature (Sharp et al., 2011). Spatial and temporal patterns in BSA and LST were, therefore, evaluated for the summer months (June-August). For each year during the 20012016 period, mean summer (JJA) BSA was calculated for pixels having at least $10 \mathrm{BSA}$ observations in each month (June, July, August) and at least 45 of a possible 92 observations during the JJA period. These monthly thresholds ensure both an even distribution of BSA data throughout the summer season and consistency between different years. Mean summer LST was calculated following the methods of Mortimer et al. (2016), where the mean summer LST is calculated for pixels having at least 7 of a possible 12 observations between 1-2 June (day 153) and 28-29 August (day 241).

The mean summer (JJA) BSA and LST and the mean monthly (June, July, August) BSA, as well as the BSA and LST anomalies, were calculated on a pixel-by-pixel basis relative to the 2001-2016 mean for pixels having mean summer observations in 11 or more years. These constituted $\sim 87 \%$ and $\sim 98 \%$ of possible BSA and LST pixels, respectively. Long-term rates of change in BSA and LST over the period 2001-2016 were determined by linear regression between the 16-year records of mean summer LST/BSA and 
time. Consistent with the BSA and LST anomalies, regressions were computed on a pixel-by-pixel basis for all pixels having mean summer observations for 11 or more years. Following Casey et al. (2017), BSA trends between -0.001 and $+0.001 \mathrm{yr}^{-1}$ are considered to be negligible. Negligible trends were defined by Casey et al. (2017) on the basis of the magnitude of the residual calibration uncertainties in the C6 data (on the order of several tenths of one percent in TOA reflectance; Lyapustin et al., 2014) over pseudo-invariant desert sites (Sect. 2.1.1).

To explore whether the data contained any spatial patterns that differed from the long-term (linear) trend, a principal component analysis of the 16-year mean summer BSA record was performed using data from all pixels with mean summer BSA observations in every year (50\% of pixels). To investigate the spatial pattern of the relationship between surface temperature (LST) and albedo (BSA), linear correlations between the 16-year LST and BSA records were computed. The MCD43A3 C6 albedo data are produced daily, whereas the MOD11A2LST data are produced only every 8 days. For this direct comparison between the LST and BSA data, 8day BSA averages were computed from the daily data for the same 8-day periods as the MOD11A2LST product and resampled to a $1 \mathrm{~km}$ spatial resolution (nearest-neighbour resampling). For each year, mean summer BSAs were computed from these 8-day averages for all pixels having at least 7 of a possible 12 observations, consistent with the computation of mean summer LST. The difference between the mean summer BSA values derived from these 8-day averages and those computed from the daily data $(\Delta 0.008)$ is within the uncertainty of MODIS reflectance products $(0.05$ for solar zenith angle $<75^{\circ}$; Vermote et al. 2011). Linear correlations between the 16-year BSA (8-day average) and LST records were then computed on a pixel-by-pixel basis for all pixels having LST and BSA observations in all 16 years (46\% of all possible pixels).

To ensure that only data for glaciated surfaces were retained, all BSA and LST outputs used in this analysis were clipped to the Randolph Glacier Inventory v3.2 region 32 (Arctic Canada North) reference polygons (Arendt et al., 2012; Pfeffer et al., 2014). Surface elevations were obtained from the Canadian Digital Elevation Dataset (CDED) edition 3.0 , scale $1: 50 \mathrm{k}$, resampled to a $500 \mathrm{~m}$ resolution.

\section{Results}

\subsection{Mean summer albedo}

Annual maps of the mean summer clear-sky broadband shortwave black-sky MCD43A3 albedo for all glaciercovered surfaces in the QEI for the 2001-2016 period are presented in Fig. 2. The QEI-wide mean summer BSA, averaged across all 16 years, was $0.550 \pm 0.115$ (mean \pm 1 standard deviation; Table 1). The lowest QEI-wide mean summer BSA $(0.539 \pm 0.127)$ was recorded in 2011 , while the highest $(0.668 \pm 0.089)$ was recorded in 2013 (Table 1).

In general, mean summer BSA is lower around the margins of the ice masses, where glacier ice is exposed in the summer, than it is in the higher-elevation interior regions, where snow or firn are exposed year-round (Fig. 2). During years when the QEI-wide mean summer BSA was low (e.g. 2011), we observed a broad zone of low albedo values $(<0.4)$ around the margins of the major ice masses (Fig. 2). Conversely, in years when the mean summer BSA was high (e.g. 2013), this zone was much less obvious. High data dropout at high elevations on Axel Heiberg Island, and over the summit of the Devon Ice Cap in 2014 and 2006 (Table S1 in the Supplement), may have produced a negative albedo bias for these regions, since the albedo is typically greater at higher elevations. Aggregating the 2001-2016 average mean summer BSA into $50 \mathrm{~m}$ elevation bins, we observed a linear rate of BSA increase with elevation $(0.0085$ per $50 \mathrm{~m}$ elevation bin, $r^{2}=0.99$ ).

In addition to the mean summer (JJA) BSA, the monthly mean BSA values for June, July, and August were also investigated (Sect. 2.3) (Table 2, Figs. S1-S3 in the Supplement). July had the lowest 16-year monthly mean BSA $(0.551 \pm 0.131)$, followed closely by August $(0.579 \pm 0.127)$ (Table 2). In each year during the 2001-2016 period, the highest summer monthly BSA was always recorded in June, while the lowest monthly BSA was recorded in either July or August. The lowest monthly mean BSA values for June and August were recorded in 2011, while the lowest July mean BSA occurred in 2012. The highest monthly mean BSA for both June and July occurred in 2013; for August, it occurred in 2003.

\subsection{Albedo anomalies}

\subsubsection{Mean summer (JJA) BSA anomalies}

The mean summer BSA anomalies, relative to the 20012016 mean, are presented in Table 1 and Fig. 3. For consistency with the regression analysis (Sect. 3.3), BSA anomalies were only computed for pixels having mean summer BSA observations in 11 or more of the 16 years (Sect. 2.3). The period 2001-2016 is characterized by a 6-year period of positive BSA anomalies (2001-06) followed by a 6year period of negative BSA anomalies (2007-2012) (Table 1). Positive BSA anomalies were also observed in 2013 $(+0.060)$ and $2014(+0.015)$, while $2015(-0.022)$ and 2016 $(-0.005)$ saw a return to negative anomalies (Table 1). Negative BSA anomalies during the period 2007-2012, which indicate a larger absorbed fraction of incoming shortwave radiation relative to the 16-year mean, coincide, and are consistent with, positive summer air and glacier surface temperature anomalies from 2007 to 2012 (Mortimer et al., 2016). Higher temperatures increase the rate of snow grain meta- 

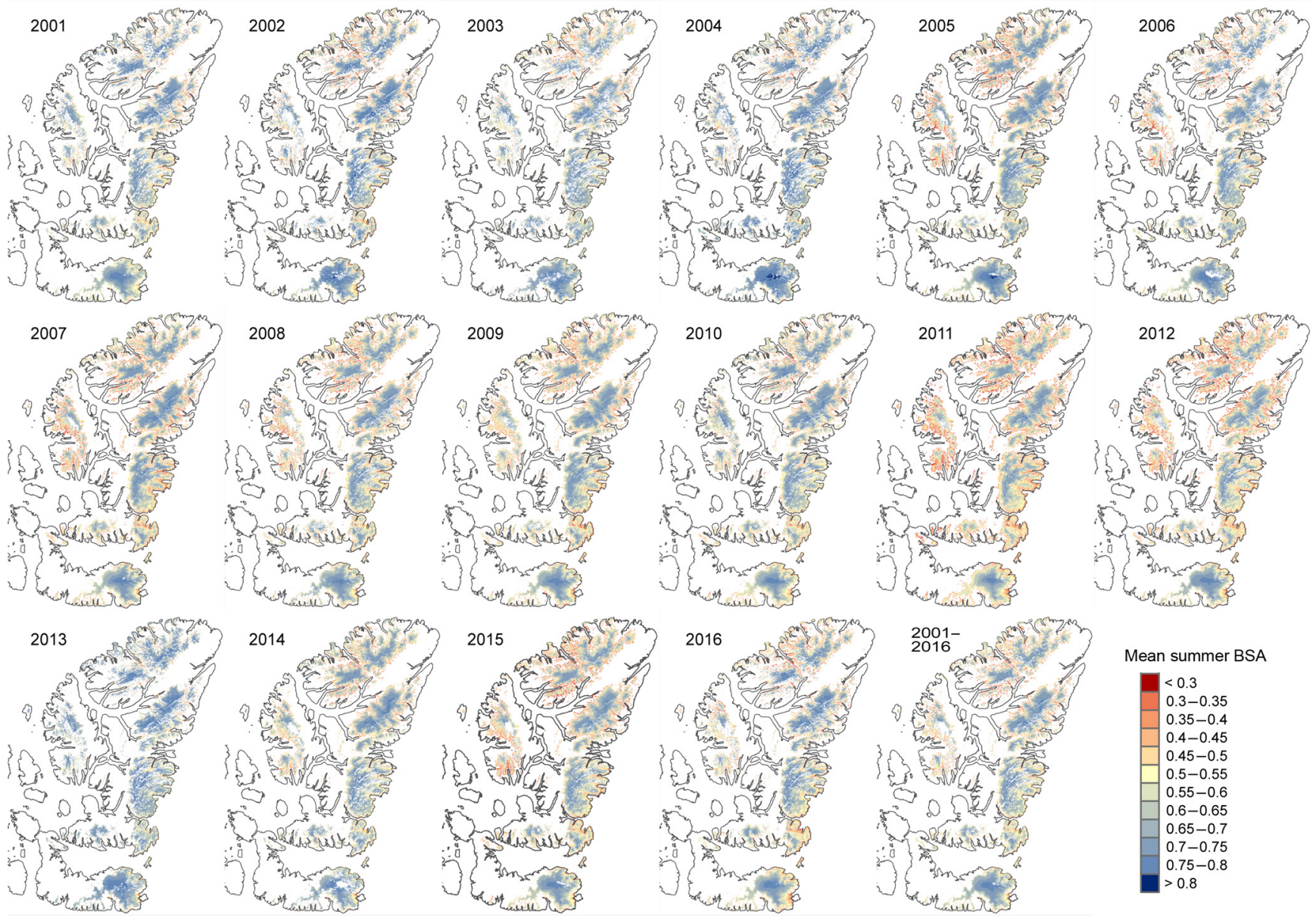

Figure 2. Mean summer clear-sky shortwave broadband black-sky albedo over the QEI ice caps. White areas outside of the ice caps indicate non-glaciated land cover.

Table 1. Clear-sky BSA and LST; \pm 1 standard deviation. Anomalies are with respect to the 2001-2016 mean.

\begin{tabular}{lrrrr}
\hline Year & BSA mean & BSA mean anomaly* & LST mean & LST mean anomaly* \\
\hline 2001 & $0.631 \pm 0.106$ & $0.0226 \pm 0.0458$ & $-3.7 \pm 2.0$ & $-0.73 \pm 0.70$ \\
2002 & $0.633 \pm 0.124$ & $0.0316 \pm 0.0320$ & $-3.5 \pm 2.2$ & $-0.51 \pm 0.68$ \\
2003 & $0.627 \pm 0.109$ & $0.0292 \pm 0.0329$ & $-3.3 \pm 1.9$ & $-0.65 \pm 0.51$ \\
2004 & $0.655 \pm 0.112$ & $0.0517 \pm 0.0318$ & $-4.0 \pm 2.4$ & $-1.07 \pm 0.80$ \\
2005 & $0.605 \pm 0.132$ & $0.0035 \pm 0.0282$ & $-2.3 \pm 1.7$ & $0.69 \pm 0.38$ \\
2006 & $0.608 \pm 0.120$ & $0.0030 \pm 0.0282$ & $-3.9 \pm 2.5$ & $-0.94 \pm 0.88$ \\
2007 & $0.586 \pm 0.125$ & $-0.0167 \pm 0.0282$ & $-1.9 \pm 1.6$ & $1.06 \pm 0.48$ \\
2008 & $0.588 \pm 0.119$ & $-0.0117 \pm 0.0212$ & $-2.4 \pm 1.4$ & $0.57 \pm 0.53$ \\
2009 & $0.586 \pm 0.115$ & $-0.0177 \pm 0.0220$ & $-2.4 \pm 1.7$ & $0.53 \pm 0.41$ \\
2010 & $0.601 \pm 0.112$ & $-0.0021 \pm 0.0307$ & $-2.1 \pm 1.7$ & $0.86 \pm 0.51$ \\
2011 & $0.539 \pm 0.127$ & $-0.0651 \pm 0.0326$ & $-2.0 \pm 1.3$ & $0.93 \pm 0.67$ \\
2012 & $0.550 \pm 0.126$ & $-0.0516 \pm 0.0309$ & $-2.1 \pm 1.4$ & $0.92 \pm 0.65$ \\
2013 & $0.668 \pm 0.086$ & $0.0604 \pm 0.0431$ & $-5.2 \pm 2.3$ & $-2.26 \pm 0.87$ \\
2014 & $0.614 \pm 0.109$ & $0.0153 \pm 0.0245$ & $-3.2 \pm 1.9$ & $-0.18 \pm 0.50$ \\
2015 & $0.578 \pm 0.124$ & $-0.0223 \pm 0.0248$ & $-2.6 \pm 1.7$ & $0.37 \pm 0.42$ \\
2016 & $0.600 \pm 0.120$ & $-0.0048 \pm 0.0334$ & $-2.5 \pm 1.9$ & $0.43 \pm 0.66$ \\
$2001-2016^{*}$ & $0.599 \pm 0.115$ & - & $-3.0 \pm 1.8$ & - \\
\hline
\end{tabular}

* Pixels having mean summer (JJA) BSA observations in at least 11 of a possible 16 years (see Sect. 2.3). 

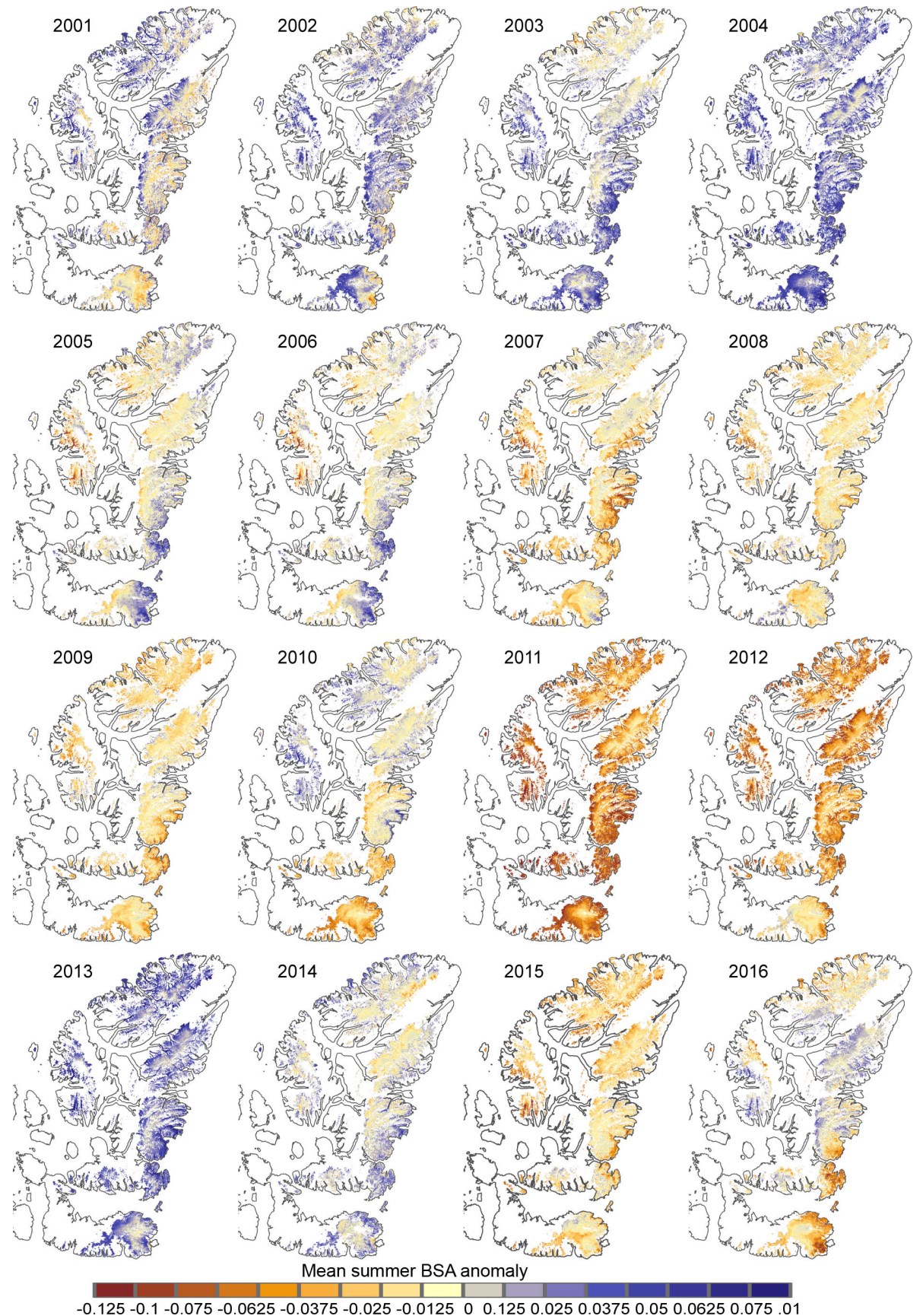

Figure 3. Mean summer clear-sky shortwave broadband albedo anomaly over the QEI ice caps relative to the 2001-2016 mean. White areas outside of the ice caps indicate non-glaciated land cover.

morphism, which lowers the surface albedo (Wiscombe and Warren, 1980; Colbeck, 1982; Warren, 1982), and a lower albedo increases the proportion of solar radiation absorbed at the ice-air interface, providing more energy for surface warming and melt. This positive-feedback mechanism may have contributed to the tripling of glacier mass loss from this region between 2004-2006 and 2007-2009 (Gardner et al., 2011).
There was no year in which the BSA anomalies for all glaciated pixels were either all positive or all negative. The lowest amount of spatial variability in mean summer BSA anomalies (Fig. 3) was observed in years when the QEI-wide mean summer BSA anomaly was either extremely positive (e.g. 2004 and 2013) or extremely negative (e.g. 2011 and 2012) (Table 1). In 2004 and 2013 (large positive QEI-wide BSA anomalies), large positive BSA anomalies $(>0.1)$ were 


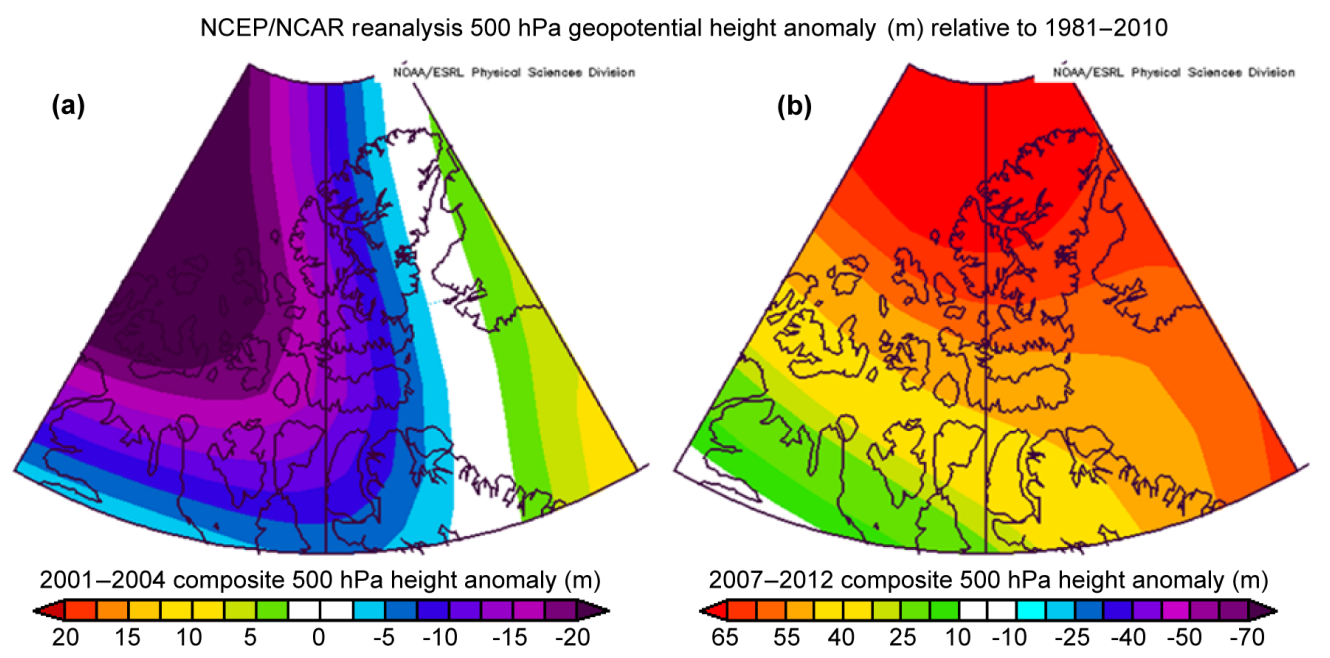

Figure 4. Mean summer (JJA) composite NCEP/NCAR Reanalysis $500 \mathrm{hPa}$ geopotential height anomaly for (a) a period of large negative BSA anomalies (2001-2004) and (b) a period of large positive BSA anomalies (2007-2012). Source: https://www.esrl.noaa.gov/psd.

Table 2. Clear-sky mean summer monthly BSA ${ }^{\mathrm{a}}$ and BSA ${ }^{\mathrm{a}}$ anomaly relative to the 2001-2016 mean for the QEI ice cover; \pm 1 standard deviation.

\begin{tabular}{|c|c|c|c|c|c|c|}
\hline Year & June & July & August & June anomaly ${ }^{b}$ & July anomalyb & August anomaly ${ }^{b}$ \\
\hline 2001 & $0.722 \pm 0.084$ & $0.584 \pm 0.127$ & $0.597 \pm 0.123$ & $0.0359 \pm 0.0502$ & $0.0285 \pm 0.0585$ & $0.0153 \pm 0.0572$ \\
\hline 2002 & $0.680 \pm 0.108$ & $0.615 \pm 0.135$ & $0.608 \pm 0.145$ & $-0.0005 \pm 0.0424$ & $0.0595 \pm 0.0435$ & $0.0270 \pm 0.0466$ \\
\hline 2003 & $0.684 \pm 0.085$ & $0.561 \pm 0.139$ & $0.658 \pm 0.127$ & $0.0003 \pm 0.0231$ & $0.0029 \pm 0.0340$ & $0.0836 \pm 0.0768$ \\
\hline 2004 & $0.714 \pm 0.085$ & $0.620 \pm 0.126$ & $0.632 \pm 0.133$ & $0.0317 \pm 0.0285$ & $0.0638 \pm 0.0465$ & $0.0501 \pm 0.0472$ \\
\hline 2005 & $0.676 \pm 0.099$ & $0.572 \pm 0.139$ & $0.573 \pm 0.143$ & $-0.0064 \pm 0.0300$ & $0.0150 \pm 0.0364$ & $-0.0116 \pm 0.0468$ \\
\hline 2006 & $0.712 \pm 0.087$ & $0.615 \pm 0.129$ & $0.568 \pm 0.137$ & $0.0255 \pm 0.0316$ & $0.0602 \pm 0.0440$ & $-0.0166 \pm 0.0431$ \\
\hline 2007 & $0.692 \pm 0.090$ & $0.544 \pm 0.141$ & $0.536 \pm 0.155$ & $0.0099 \pm 0.0228$ & $-0.0143 \pm 0.0339$ & $-0.0518 \pm 0.0494$ \\
\hline 2008 & $0.660 \pm 0.104$ & $0.533 \pm 0.148$ & $0.576 \pm 0.118$ & $-0.0220 \pm 0.0298$ & $-0.0226 \pm 0.0353$ & $-0.0050 \pm 0.0345$ \\
\hline 2009 & $0.690 \pm 0.089$ & $0.536 \pm 0.132$ & $0.533 \pm 0.142$ & $0.0085 \pm 0.0258$ & $-0.0212 \pm 0.0310$ & $-0.0544 \pm 0.0383$ \\
\hline 2010 & $0.668 \pm 0.091$ & $0.528 \pm 0.136$ & $0.606 \pm 0.136$ & $-0.0143 \pm 0.0230$ & $-0.0289 \pm 0.0331$ & $0.0188 \pm 0.0656$ \\
\hline 2011 & $0.628 \pm 0.101$ & $0.480 \pm 0.147$ & $0.521 \pm 0.148$ & $-0.0557 \pm 0.0347$ & $-0.0770 \pm 0.0400$ & $-0.0657 \pm 0.0517$ \\
\hline 2012 & $0.628 \pm 0.112$ & $0.478 \pm 0.146$ & $0.559 \pm 0.137$ & $-0.0532 \pm 0.0395$ & $-0.0805 \pm 0.0399$ & $-0.0243 \pm 0.0532$ \\
\hline 2013 & $0.724 \pm 0.072$ & $0.640 \pm 0.107$ & $0.628 \pm 0.109$ & $0.0402 \pm 0.0406$ & $0.0843 \pm 0.0517$ & $0.0466 \pm 0.0637$ \\
\hline 2014 & $0.698 \pm 0.080$ & $0.572 \pm 0.128$ & $0.584 \pm 0.136$ & $0.0167 \pm 0.0277$ & $0.0148 \pm 0.0335$ & $0.0026 \pm 0.0495$ \\
\hline 2015 & $0.677 \pm 0.103$ & $0.490 \pm 0.143$ & $0.587 \pm 0.147$ & $-0.0033 \pm 0.0282$ & $-0.0675 \pm 0.0400$ & $0.0026 \pm 0.0457$ \\
\hline 2016 & $0.675 \pm 0.089$ & $0.545 \pm 0.146$ & $0.589 \pm 0.146$ & $-0.0066 \pm 0.0280$ & $-0.0146 \pm 0.0354$ & $0.0049 \pm 0.0652$ \\
\hline $2001-2016^{\mathrm{b}}$ & $0.680 \pm 0.089$ & $0.551 \pm 0.131$ & $0.579 \pm 0.127$ & - & - & - \\
\hline
\end{tabular}

${ }^{a}$ Average of all pixels in each region having at least 11 (10 for June) of a possible 31 (30 for June) observations (see Sect. 2.3).

b Pixels having June BSA observations in at least 11 of a possible 16 years (see Sect. 2.3).

observed at lower elevations around the margins of the ice masses, while BSA anomalies were near zero at higher elevations in the interiors of the ice masses (Fig. 3). In 2011 and 2012 (large negative QEI-wide BSA anomalies), a similar spatial pattern, but with anomalies of opposite sign, was observed.

The largest amount of spatial variability in the mean summer BSA occurred in years when the QEI-wide BSA anomaly was near zero (between $\sim-0.0048$ and +0.0030 ; Table 1). In 2005, 2006, and 2016, BSA anomalies in a region that includes the eastern half of the Devon Ice Cap, the ma- jority of the Manson Icefield, and the southernmost portion of the Prince of Wales Icefield were often opposite to those observed in the rest of the QEI (Fig. 3). These regions are in close proximity to open water sources in Baffin Bay (Fig. 1), which is the largest moisture source for the QEI (Koerner, 1977). Variability in the extent of open water in the QEI's interisland channels has previously been correlated with the variability in summer temperatures (Koerner, 1977) and the $500 \mathrm{hPa}$ geopotential height anomalies in the QEI (Bezeau et al., 2015). Nearby open water sources may serve to moderate the surface albedo variability in this eastern maritime 

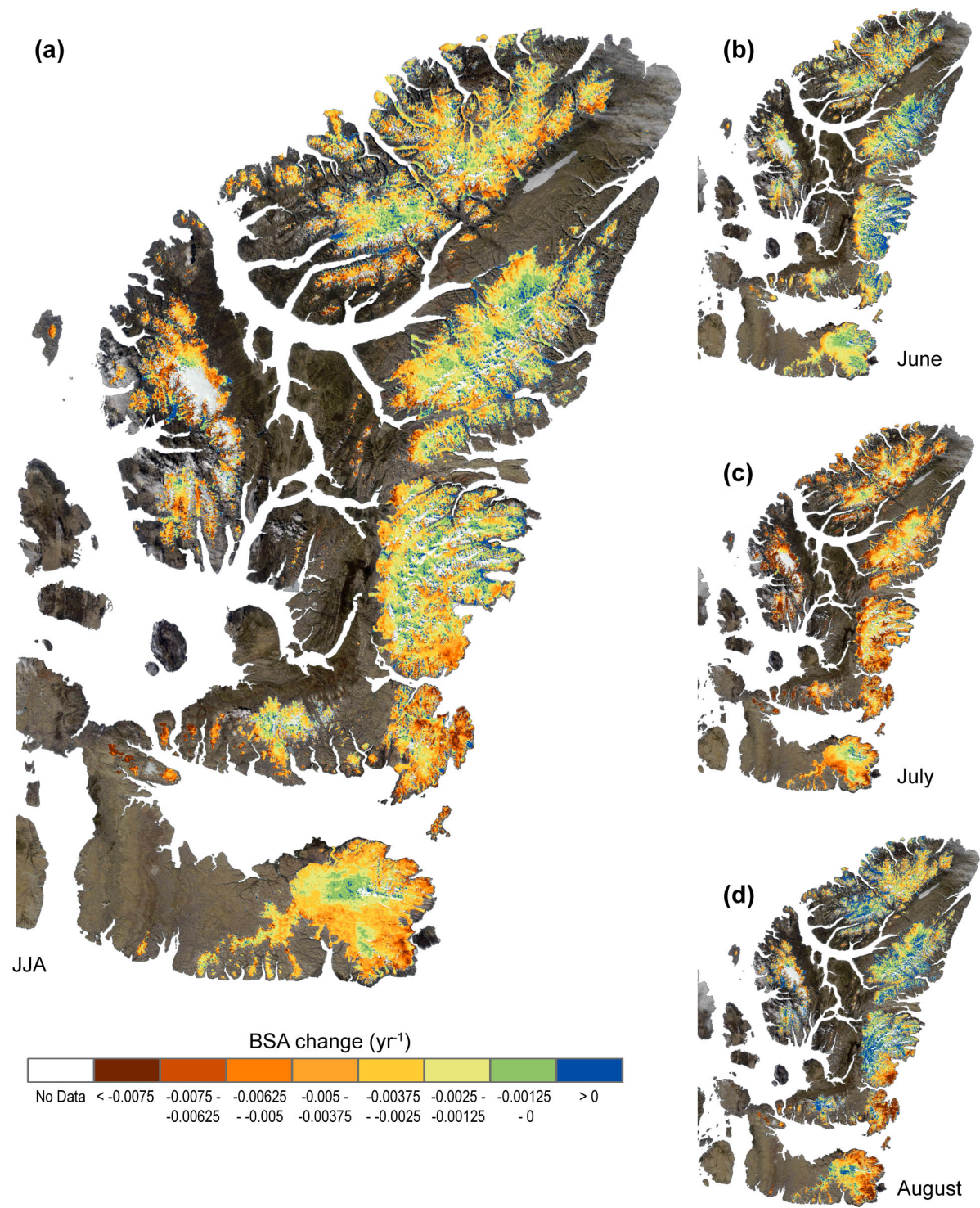

Figure 5. Linear rate of change $\left(\mathrm{yr}^{-1}\right)$ in (a) mean summer (JJA), (b) June, (c) July, and (d) August clear-sky shortwave broadband black-sky albedo for 2001-2016 over the QEI ice caps. Background image: MODIS, 4 July 2011. Brown indicates non-glaciated land cover.

region through more frequent and/or persistent snowfall and riming events in warm summers when the open water extent is large (Koerner, 1977, 1979; Alt, 1978).

In 2005 and 2006 (years when the mean summer QEIwide BSA anomaly was near zero and there was a large amount of spatial variability in the mean summer BSA), BSA anomalies on the westernmost part of Axel Heiberg Island (Fig. 3) were of the same sign and double the magnitude of the QEI-wide BSA anomaly (Table 1). A similar spatial feature (large anomaly values on western Axel Heiberg Island of the same sign as the QEI-wide anomaly) was also observed in the LST anomaly record in 2005 (Fig. S7). Examination of the $500 \mathrm{hPa}$ geopotential height anomalies for 2001-2016 in NCEP/NCAR R1 data (Kalnay et al., 1996; https://www.esrl.noaa.gov/psd) shows that in years when the mean summer QEI-wide BSA anomaly was strongly negative (e.g. 2001-2004) (or positive (e.g. 2007-2012)) a persistent ridge (trough) was centred over the north and west of the QEI (which includes Axel Heiberg Island) (Fig. 4). These circulation features are likely responsible for the strong negative BSA anomalies observed over Axel Heiberg Island because clear-sky conditions that accompany anticyclonic circulation increase the proportion of incoming shortwave radiation received at the air-ice interface, providing more energy for melt and driving albedo declines.

\subsubsection{Summer monthly BSA anomalies}

In addition to the mean summer (JJA) BSA anomalies, the mean June, July, and August BSA anomalies were also ex- 


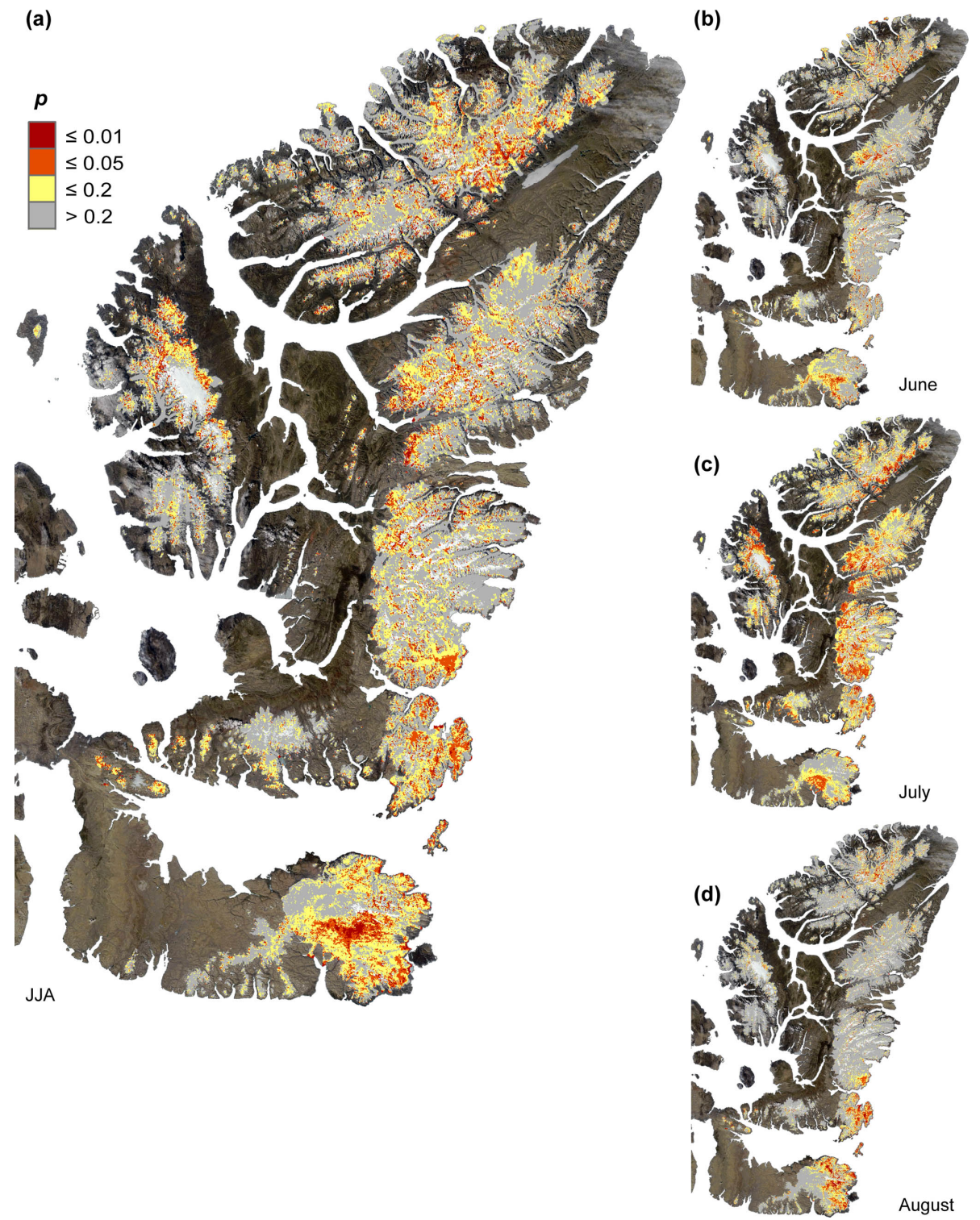

Figure 6. $p$ value of the linear regression (Fig. 5) of (a) mean summer (JJA), (b) June, (c) July, and (d) August clear-sky shortwave broadband black-sky albedo for the period 2001-2016 over the QEI ice caps. Background image: MODIS, 4 July 2011. Brown indicates non-glaciated land cover.

amined (Figs. S4-S6) (Sect. 2.3). The sign of the mean July BSA anomaly (Table 2) was always consistent with that of the mean summer (JJA) BSA anomaly (Table 1). In contrast, the sign of the mean June and August QEI-wide BSA anomaly was often opposite to that of the mean summer BSA anomaly. In June, negative QEI-wide BSA anomalies occurred in 2002 and 2005 when the mean summer QEIwide BSA anomaly was positive, while positive QEI-wide June BSA anomalies occurred in 2007 and 2009 when the mean summer BSA anomaly was negative. Negative QEIwide BSA anomalies occurred in August 2005 and 2006, when the QEI-wide mean summer anomaly was positive. Positive BSA anomalies occurred in August 2010, 2015, and
2016, when the QEI-wide mean summer anomaly was negative.

There are also distinct differences in the large-scale spatial patterns of the BSA anomaly between months. In years with strong negative (positive) QEI-wide June BSA anomalies, most of the ice-covered pixels also had negative (positive) anomalies in this month (Fig. S4). In contrast, in years with weak negative QEI-wide June BSA anomalies (e.g. 2002), positive (June BSA) anomalies occurred in the southeast, while negative BSA anomalies occurred in the west and northwest (Fig. S4). The opposite scenario occurred in years with weak positive QEI-wide June BSA anomalies (e.g. 2003). 

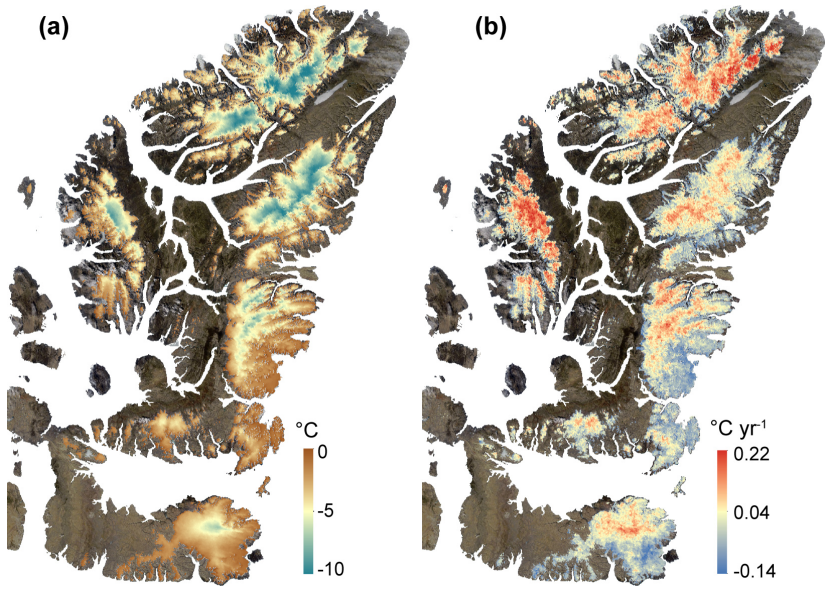

Figure 7. QEI (a) 16-year average mean summer land surface temperature $\left({ }^{\circ} \mathrm{C}\right)$ and (b) linear rate of change of mean summer LST $\left({ }^{\circ} \mathrm{C} \mathrm{yr}^{-1}\right)$ for the period 2001-2016 over the QEI ice caps. Background image: MODIS, 4 July 2011. Brown indicates non-glaciated land cover.

In July (Fig. S5) (the month with the lowest QEI-wide BSA; Table 2), BSA anomalies were typically both large (between -0.0805 and +0.0843$)$ and less spatially variable than in either June or August (Figs. S4 and S6). However, in some years (e.g. 2005) July BSA anomalies in the southeast maritime region that includes the eastern part of the Devon Ice Cap, Manson Icefield, and the southeasternmost part of the Prince of Wales Icefield were opposite in sign to those over the rest of the QEI. Nearby open water sources may have moderated the BSA in this region (Sect. 3.2.1).

Mean August BSA anomalies displayed higher spatial variability than July anomalies but were typically of similar magnitude $(-0.0657$ to +0.0836 ; Table 2$)$. Unlike the June BSA anomalies (Fig. S4), which are characterized by a northwest-southeast spatial pattern, spatial variations in the August BSA anomaly are more local (zonal) in nature (Fig. S6). Cyclonic circulation is much more prevalent over the QEI in August than in June and July (Alt, 1987; Gascon et al., 2013). The zonal nature of the August BSA anomaly likely reflects localized snowfall events related to the passage of individual low-pressure systems, associated with cyclonic circulation conditions. These snowfalls would temporarily raise the surface albedo in affected regions.

\subsection{Albedo change: 2001-2016}

\subsubsection{Mean summer BSA change}

To determine whether there was a measurable change in the summer surface albedo over the period 2001-2016, we performed a linear regression. Regressions were performed on a pixel-by-pixel basis for all pixels having mean summer BSA observations in at least 11 of the 16 years of observation (Sect. 2.3). The QEI-wide rate of change was taken as the average of these pixels. Between 2001 and 2016 the mean summer (JJA) QEI-wide BSA decreased at a rate of $0.0029 \pm$ $0.0025 \mathrm{yr}^{-1}$ (Table 3, Fig. 5a). More than $95 \%$ of pixels experienced a non-negligible ( $>|0.001| \mathrm{yr}^{-1}$; Sect. 2.3$)$ decrease in summer BSA, and the total BSA change $(-0.046)$ exceeds the MODIS sensor capabilities ( $2 \%$ in absolute reflectance units for the reflective solar bands $(0.41-2.2 \mu \mathrm{m}$; Justice et al., 1998)) (Sect. 2.1), suggesting that the mean summer BSA did decline somewhat during this 16-year period. Although the measured change in the QEI-wide mean summer BSA (average correlation coefficient of all pixels) was not statistically significant $(r=0.31, p=0.24)$, BSA declines that were significant at the $p \leq 0.05$ level were observed at the pixel scale on all ice masses (Fig. 6a). The BSA change reported here is comparable to, although slightly larger than, that identified for the Greenland Ice Sheet's wet snow zone over the same time period (2001-2016) using similar data $\left(-0.0025 \mathrm{yr}^{-1}\right.$ for MCD43A3 Band 4 (0.545$0.565 \mu \mathrm{m})$; Casey et al., 2017).

Between 2001 and 2016, the area-averaged mean summer (JJA) incoming solar radiation over ice-covered surfaces in the QEI, computed from daily means of NCEP/NCAR R1 data (Kalnay et al., 1996) (http://www.esrl.noaa.gov/psd/ data/gridded/), ranged from $346 \mathrm{~W} \mathrm{~m}^{-2}$ (clear-sky downward solar flux) to $299 \mathrm{~W} \mathrm{~m}^{-2}$ (all-sky downward solar flux). Assuming the solar radiation received at the surface was constant over the 16-year period, our measured BSA reduction $\left(-0.0029 \mathrm{yr}^{-1}\right)$ translates to a total increase in area-averaged absorbed solar radiation of between 1.1 and $1.4 \mathrm{MJ}$ over the 16-year period. For a surface already at the melting point, this would equate to an increase in (area-averaged) summer melt of between 0.38 and 0.44 mw.e. (Table 5.1 in Cuffey and Paterson, 2010).

Spatially, large reductions in the mean summer BSA $(<$ $-0.005 \mathrm{yr}^{-1}$ ) occurred at lower elevations around the margins of the ice masses (where the mean summer BSA is lowest), especially on Axel Heiberg Island, northern Manson Icefield, and the climatically continental interior regions of the ice masses on Ellesmere Island (Fig. 5a). Many of these BSA declines were significant at the $p \leq 0.05$ level (Fig. 6a). Statistically significant BSA declines $\left(\sim-0.00357 \mathrm{yr}^{-1}\right.$, $p \leq 0.05)$ also occurred in the interior of the Manson Icefield and on the southern half of the Devon Ice Cap (Figs. 5a and 6a). Although BSA declines tended to be larger at lower elevations, slight BSA increases $\left(>0.001 \mathrm{yr}^{-1}\right.$, not statistically significant) were observed along the lower portions of outlet glaciers (Fig. 6a). Many of these glaciers are close to open water sources where coastal fog may play a role in reducing summer melt, thereby suppressing albedo decreases (Alt, 1987). No measurable changes in mean summer BSA were observed over the high-elevation ( $>\sim 1500$ ma.s.1.; $>\sim 1200 \mathrm{~m}$ a.s.l. for Sydkap Ice Cap) interior regions of the Sydkap Ice Cap, Agassiz Ice Cap, Prince of Wales Icefield, or northern Ellesmere Island ice caps (Fig. 5a), even though 

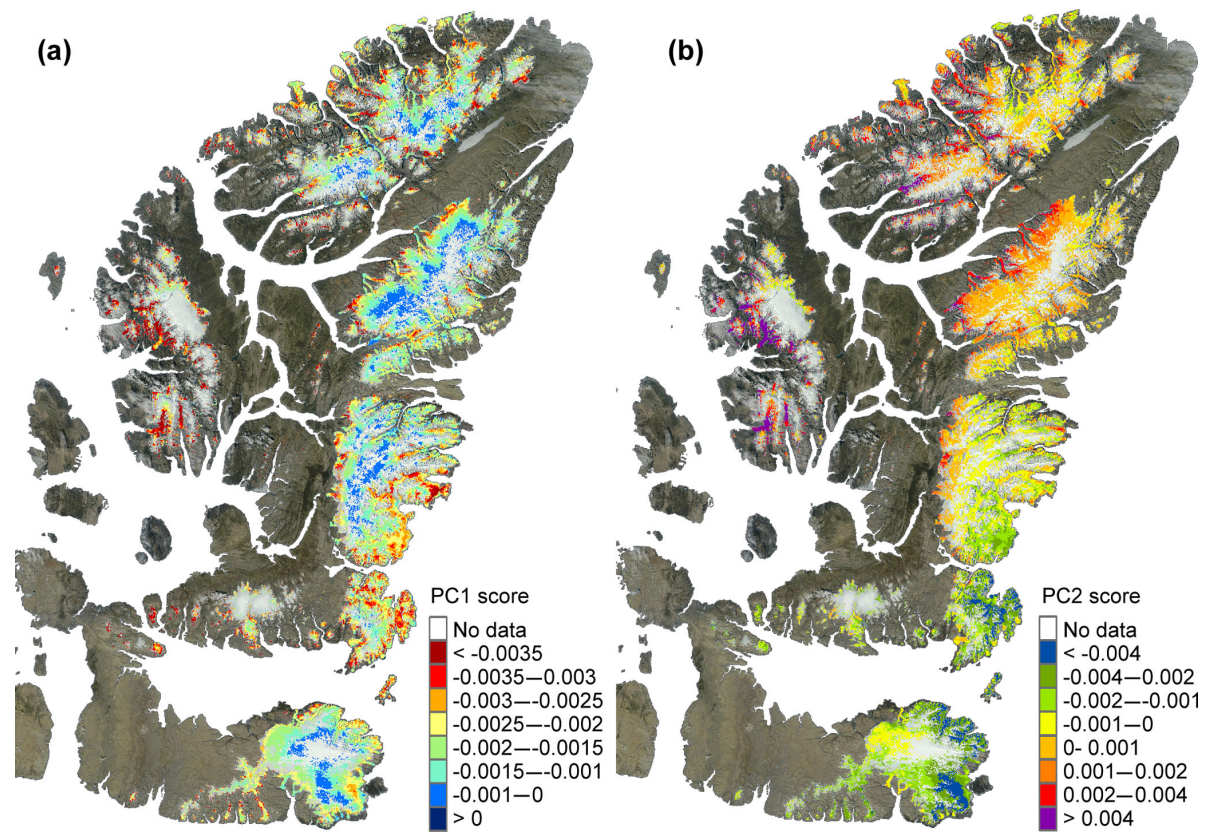

Figure 8. Component scores for the first two principal components of the mean summer clear-sky BSA (Fig. 2) over the QEI ice caps. Background image: MODIS, 4 July 2011. Brown indicates non-glaciated land cover.

Table 3. QEI-wide (regionally averaged) BSA and LST change for the period 2001-2016; \pm 1 standard deviation.

\begin{tabular}{ccccc}
\hline JJA mean BSA $\left(\mathrm{yr}^{-1}\right)$ & Jun mean BSA $\left(\mathrm{yr}^{-1}\right)$ & Jul mean BSA $\left(\mathrm{yr}^{-1}\right)$ & Aug mean BSA $\left(\mathrm{yr}^{-1}\right)$ & \left.${\mathrm{JJA} \mathrm{LST}\left({ }^{\circ} \mathrm{C} \text { yr}\right.}^{-1}\right)$ \\
\hline$-0.0029 \pm 0.0025$ & $-0.0017 \pm 0.0024$ & $-0.0050 \pm 0.0031$ & $-0.0022 \pm 0.0036$ & $+0.049 \pm 0.038$ \\
\hline
\end{tabular}

strong increases in $\operatorname{LST}\left(>0.1^{\circ} \mathrm{C} \mathrm{yr}^{-1}\right)$ were observed in these locations between 2001 and 2016 (Fig. 7).

\subsubsection{Summer monthly BSA change}

In addition to the mean summer (JJA) BSA change, trends in the mean monthly (June, July, and August) BSA were also investigated (Sect. 2.3). Maps of the mean monthly BSA change, presented in Fig. 5b-d, illustrate differences in the spatial patterns of BSA change for each summer month. There was a large (but not statistically significant at the $p<0.05$ level) decrease in the QEI-wide mean July BSA $\left(-0.0050 \pm 0.0031 \mathrm{yr}^{-1}, r=0.38, p=0.15\right)$, but no QEIwide change was observed in either June or August (Table 3). This suggests that the bulk of the mean summer (JJA) BSA decline occurred in the month of July. In July, $>93 \%$ of pixels exhibited a non-negligible decrease in BSA (Fig. 5c), and $24 \%$ of the measured (July) BSA declines were significant at the $p<0.05$ level (Fig. 6c). The spatial pattern of July BSA change (Fig. 5c) is similar to that of the mean summer BSA change (Fig. 5a), with the largest BSA declines occurring at lower elevations. In July, statistically significant $(p<0.05)$ BSA decreases occurred in the climatically continental interior regions of all the ice masses on northern Ellesmere
Island, the northern half of Axel Heiberg Island, southern Prince of Wales Icefield, northern Manson Icefield, and the southwest Devon Ice Cap (Figs. 5c and 6c).

Although there was no measurable change in the QEIwide BSA in either June $\left(-0.0017 \pm 0.0024 \mathrm{yr}^{-1}\right)$ or August $\left(-0.0022 \pm 0.0036 \mathrm{yr}^{-1}\right)$, owing to the large amount of spatial variability in the sign and magnitude of BSA changes in these months, notable clusters of consistent BSA change are observed (Fig. 5b and d). In June, increases in BSA occurred on the eastern portions of Prince of Wales Icefield and Agassiz Ice Cap, while weak-to-moderate BSA declines $\left(>\sim-0.005 \mathrm{yr}^{-1}\right)$ occurred elsewhere (Fig. 5b). In June, only $10 \%$ of pixels had BSA trends that were significant at the $p \leq 0.05$ level. These pixels are found mainly on the southwestern parts of the Devon and Agassiz ice caps, and on northwest Ellesmere Island (Fig. 6b).

In August, large and statistically significant BSA decreases $\left(<-0.00625 \mathrm{yr}^{-1}, p \leq 0.05\right)$ occurred on the eastern Devon Ice Cap, Manson Icefield, and southeast Prince of Wales Icefield (Figs. 5d and 6d). Moderate declines in August mean BSA $\left(<-0.005 \mathrm{yr}^{-1}, p \leq 0.05\right)$ occurred on the ice fields on the northern half of northwest Ellesmere Island. The mean August BSA increased on the summits of the Devon and Sydkap ice caps, the western part of the 

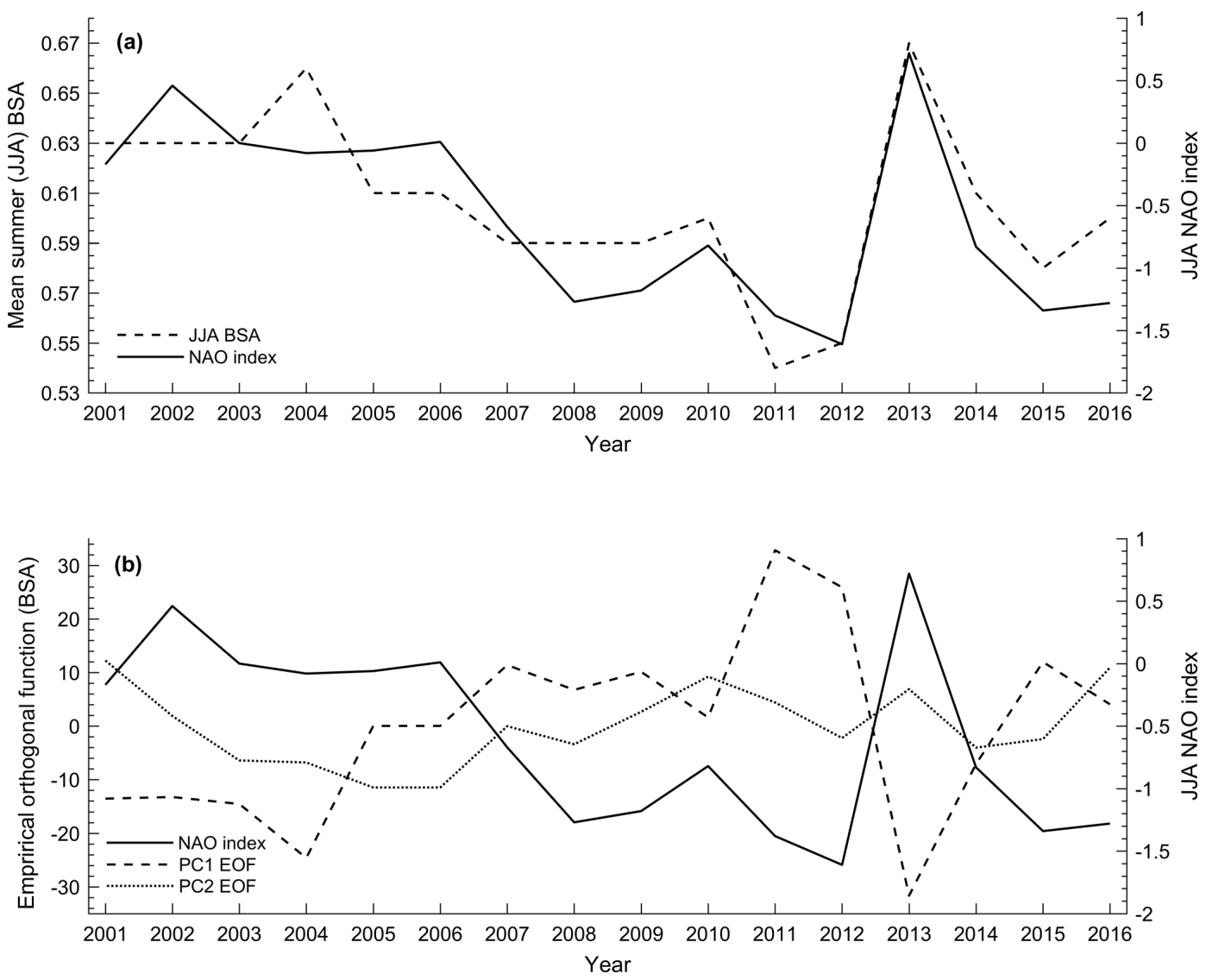

Figure 9. (a) mean summer (JJA) clear-sky shortwave broadband black-sky albedo (left-hand axis) and the mean summer (JJA) NAO index (right-hand axis) for 2001-2016. (b) Empirical orthogonal functions (EOFs) for the first and second principal components of the 16-year mean summer (JJA) BSA record (left-hand axis), and the mean summer (JJA) NAO index (right-hand axis) for 2011-2016 (Sect. 3.4).

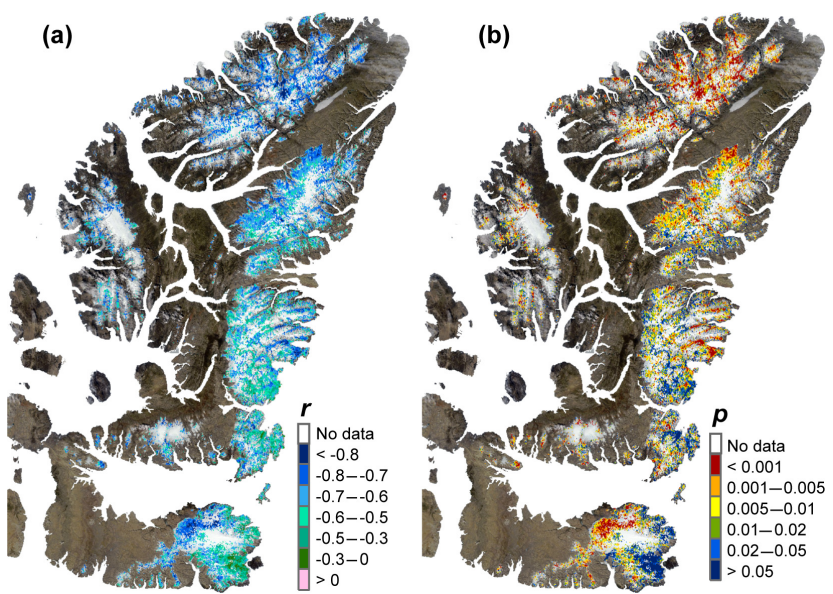

Figure 10. (a) Pearson correlation coefficient $(r)$ and (b) $p$ value for linear regression of the 16-year BSA and LST record for the QEI ice caps. Background image: MODIS, 4 July 2011. Brown indicates non-glaciated land cover.
Prince of Wales Icefield, some eastern and southerly sections of the Agassiz Ice Cap, and some outlet glaciers in northwest Ellesmere Island and Axel Heiberg Island (Fig. 5d). However, these increases were not statistically significant (Fig. 6d).

\subsection{Principal component analysis}

To explore whether there are any other spatial patterns in the 16-year mean summer BSA record that differ from the long-term (linear) trend, we performed a principal component analysis of the BSA record (Sect. 2.3). The first and second principal components (Fig. 8) explain 65 and $12 \%$ of the variance in the mean summer BSA record, respectively. The spatial pattern of the first principal component (PC1) scores (Fig. 8a) is generally consistent with the spatial patterns of summer (JJA, Fig. 5a) and July (Fig. 5c) mean BSA change described previously (Sect. 3.3). PC1 scores are strongly negative $(<-0.005)$ on western Axel Heiberg Island (large BSA declines) and weakly negative ( $>-0.001$ ), or even positive, at high elevations in the interiors of the ice masses, where there was no change in the mean summer BSA. Moderately 
negative $(\sim-0.002)$ component scores occur on the western (continental) side of eastern Ellesmere Island's ice masses as well as over much of Manson Icefield and the southeast portion of Prince of Wales Icefield, where large decreases were observed in both the summer (JJA) and the July BSA.

For $\mathrm{PC} 1$, the highest empirical orthogonal functions (EOFs) (32.8 and 25.9) correspond to the years with the lowest mean summer BSA (2011 and 2012) (Fig. 9). The lowest EOFs ( -31.7 and -24.6$)$ correspond to the years with the highest mean summer BSA (2013 and 2004) (Fig. 9). In addition, the departure from zero is much larger for the minimum component scores than for the maximum component scores (Fig. 8a), suggesting that both positive and negative BSA anomalies are likely caused by forcings with the same spatial pattern, albeit with the opposite sign. Investigating possible relationships between surface albedo and known large-scale patterns of atmospheric variability (Arctic Oscillation, Pacific-North American teleconnection pattern, North Atlantic Oscillation), we found the EOFs for PC1 to be well (negatively) correlated with the mean summer North Atlantic Oscillation (NAO) index ( $r=-0.84, p<0.001$, Fig. 9), derived by averaging the June-August monthly mean NAO indices for 2001-2016 (http://www.cpc.ncep.noaa.gov). This is consistent with the finding of Mortimer et al. (2016) that there was a good agreement between the mean summer LST record and the NAO index in the QEI over the 2000-2015 period.

The second principal component (PC2) had the largest EOFs of any component in 2006, 2010, and 2016. In these years, there was poor correspondence between the PC1 EOFs and the JJA NAO index (Fig. 9). The spatial pattern of the PC2 scores (Fig. 8b) resembles that of the August BSA change (Fig. 5d). Large negative PC2 scores $(<-0.004)$ were observed on eastern Devon Ice Cap and Manson Icefield, where large August BSA declines $\left(<-0.0075 \mathrm{yr}^{-1}\right)$ occurred. Positive PC2 scores (Fig. 8b) were observed in southwest Axel Heiberg Island and at lower elevations on northern Ellesmere Island's southwestern ice caps, where the mean August BSA increased (Fig. 5d). Unlike PC1, there were no significant correlations between the EOFs of PC2 and known large-scale patterns of atmospheric variability.

\subsection{Comparison with the mean summer LST}

Owing to the positive feedback between albedo and surface temperature, we would expect to observe strong increases in surface temperature where albedo declines were large. To investigate this relationship over the QEI, the 16year mean summer LST record was compared with the 16year mean summer BSA record (Sect. 2.3). Because of the 8 day averaging period of the MOD11A2 data used here, the mean monthly BSA were not included in this comparison (Sect. 2.3). Between 2001 and 2016, the mean summer LST $\left(-3.0 \pm 1.8^{\circ} \mathrm{C}\right)$ increased at a rate of $0.049 \pm 0.038^{\circ} \mathrm{C} \mathrm{yr}^{-1}$ (Table 3). LST increases (Fig. 7b) were greatest at higher el- evations where the mean summer LST is lower (Fig. 7a). In contrast, BSA decreases (Fig. 5a) were largest at lower elevations where the mean summer BSA was lowest (Fig. 2). This observation may be explained by the fact that at lower elevations, where the mean summer LST regularly reached the melting point, there was less potential for warming than at higher elevations (Mortimer et al., 2016).

As expected, the 16-year QEI-wide LST record was negatively correlated $(r=-0.86)$ with the 16-year QEI-wide BSA record. This negative correlation points to a positive ice-albedo feedback that would enhance rates of glacier mass loss from the QEI. Spatially, correlations (derived from linear correlations between the 16-year LST and BSA records for each pixel (Sect. 2.3)) were strongly negative in the north and west of the QEI (Fig. 10). Weak negative correlations (Fig. 10) occurred on the southwest Devon Ice Cap and Manson Icefield where LST decreased (Fig. 7b) and BSA increased (Fig. 5a). In these regions, where the mean summer LST is high, the weak correlations between LST and BSA may reflect the fact that the albedo continues to decline once the surface temperature has reached the melting point. We note, however, that the large amount of missing data limits our ability to discern broad spatial patterns of the relationship between LST and BSA in the QEI.

\section{Discussion}

Between 2001 and 2016 the bulk of the measured mean summer BSA declines in the QEI occurred in July (Sect. 3.2). This finding is consistent with previous work (e.g. Alt, 1987; Gardner and Sharp, 2007) that found variability in July nearsurface air temperatures to be the primary influence on interannual variability in annual QEI mass balance. Variability in July air temperatures has, in turn, been associated with variations in the strength, position, and geometry of the July circumpolar vortex (Gardner and Sharp, 2007). Extreme highmelt years in the QEI are associated with the intrusion of a steep ridge at all levels in the troposphere and the absence of the North American trough, making the QEI thermally homogeneous with continental North America (Alt, 1987). Between 2001 and 2016, in years with low (e.g. 2007-2012) (high (e.g. 2001-2004)) albedos, there was a persistent ridge (trough) in the $500 \mathrm{hPa}$ geopotential height surface centred over the north and west of the QEI (Fig. 4; Sect. 3.1.1). This configuration appears to be tied to the increased warming and albedo declines observed in the central western part of the QEI between 2007 and 2012. For example, strong warming (Fig. 7b) and albedo declines (Fig. 5a) over Axel Heiberg Island and north-central Ellesmere Island coincided with a ridge of high pressure centred over the north and west of the QEI (Fig. 4) that was often observed in years when the NAO index was negative (Fig. 9).

Differences in the spatial patterns of the monthly BSA change (Fig. 5b-d) reflect the dominant atmospheric circu- 
lation patterns that occur over the QEI during the summer months. In the QEI, anticyclonic circulation tends to dominate in the months of June and July, while cyclonic circulation often occurs in August (Alt, 1987; Gascon et al., 2013). In June and July, the largest BSA declines occurred in the climatically continental interiors of the ice masses on Ellesmere and Devon islands, as well as on Axel Heiberg Island (Fig. 5). In these months, the mountains on eastern Ellesmere and Devon Islands act as a barrier to moisture transport from the east, limiting (solid) precipitation (which can temporarily raise the surface albedo) on the western (lee) side of the eastern ice masses (Koerner, 1979). Adiabatic heating of descending air masses on the western (lee) side of the eastern ice masses results in warm dry air, which promotes warming, melting, and enhanced albedo declines. In contrast, in August, when cyclonic circulation is common (Sect. 3.2.1), BSA declines were largest at low elevations in the maritime regions of eastern Devon Ice Cap, Manson Icefield, and the southwestern Prince of Wales Icefield (Fig. 5d). Low-pressure systems which track from the southwest to the north and northeast are common in August, and they advect warm moist air into the Arctic from the south (Alt, 1987; Gascon et al., 2013). In the eastern QEI, orographic uplift of air masses tracking from the southwest, and subsequent adiabatic heating of these air masses when they descend on the eastern sides of ice masses, would bring warm dry air to the eastern (lee) side of the mountains in the eastern QEI, promoting both warming and albedo decline in these regions in August.

During the 2001-2016 period, the mean summer QEIwide BSA record was strongly tied to the summer NAO index (Sect. 2.4). Anticyclonic circulation was shown to co-vary with the NAO index over the Greenland Ice Sheet, immediately to the east of the QEI, from $\sim 2001$ onwards (Rajewicz and Marshall, 2014). On the Greenland Ice Sheet, clear-sky conditions and the advection of warm air form the south that accompany anticyclonic ridging (Rajewicz and Marshall, 2014), similar to that observed in the QEI in June and July (Alt, 1987; Gascon et al., 2013; Bezeau et al., 2015), were found to enhance the strength of the ice-albedo feedback between 2009 and 2011, which resulted in higher rates of melt and glacier mass loss (Box et al., 2012). Although a similar phenomenon is likely to have occurred in the QEI, we find that in some years $(2006,2010,2016)$ there was poor correspondence between the mean summer BSA record and the NAO index (Fig. 9), suggesting that an additional forcing may be influencing the spatial and temporal variability of glacier surface albedo in the QEI.

The spatial pattern of both QEI snow accumulation (Figs. 2 and 3 in Koerner, 1979) and $\partial^{18} \mathrm{O}$ values (Fig. 7 in Koerner, 1979) was inferred by Koerner (1979) for the 1962-1973 period from surface snow samples and shallow firn cores collected in spring 1974. These spatial patterns (of snow accumulation and $\partial^{18} \mathrm{O}$ ) closely resemble the spatial pattern of PC2 scores (Fig. 8). Specifically, areas having large negative PC2 scores $(<-0.002$; Fig. 8b) of the 16-year mean summer BSA record (Sect. 3.4) were characterized by relatively high accumulation rates (Fig. 2 and 3 in Koerner, 1979) and snow that is isotopically warm (Fig. 7 in Koerner, 1979), while areas with positive PC2 scores had lower snow accumulation rates. This similarity points to a possible role of precipitation in affecting the mean summer BSA in some years. To investigate the relationship between the albedo record and variability in precipitation, we examined the cumulative mass change record for the QEI from the Gravity Recovery and Climate Experiment (GRACE; Wolken et al., 2016, extended to 2016; Bert Wouters, personal communication, 2017). The record shows that in 2006, 2010, and 2016 (the years when PC2 of the 16-year mean summer BSA record had the largest EOFs of any principal component; Sect. 3.4), once the annual minimum glacier mass was reached, there was a prolonged period of constant low mass (i.e. no melt or snowfall) before fall/winter accumulation began (inferred from an increase in mass). In other years, there was a sharp transition from the local end-of-summer mass minimum to the period of seasonally increasing mass. This could indicate that in some years during the 2001-2016 period, variability in August snowfall may have influenced the mean summer BSA.

\section{Conclusions}

This study presents the first complete picture of mean summer surface albedo variations over all glaciated surfaces in the QEI during the period 2001-2016. Mean summer shortwave broadband black-sky albedo decreased at a rate of $0.0029 \pm 0.0025 \mathrm{yr}^{-1}$ over the 16 -year period. Strong negative BSA anomalies from 2007 to 2012 suggest that the bulk of the observed albedo decline occurred during this 6-year period. Large albedo declines occurred in July $(-0.0050 \pm$ $\left.0.0031 \mathrm{yr}^{-1}\right)$, while no change in BSA occurred in either June or August, indicating that the bulk of the mean summer BSA decrease is concentrated in July, when strong anticyclonic circulation occurs. The 16-year history of mean summer BSA changes is strongly tied to variations in the summer NAO index, except in the years 2006, 2010, and 2016, when changes in the mean summer BSA appear to be dominated by the effect of changes in the mean August BSA. Albedo declines were largest at low elevations around the margins of the ice masses, and the 16-year record of mean summer BSA was negatively correlated with the 16-year record of mean summer LST, suggesting the existence of a positive ice-albedo feedback that would enhance rates of glacier mass loss from the QEI in a warming climate.

Declines in albedo increase the proportion of incoming solar radiation absorbed at the air-ice interface, and thus the energy available to drive melt, warming, and further surface albedo decline. Warmer temperatures, in turn, increase the rate of snow grain metamorphism, which lowers 
the albedo. Air and surface temperatures affect the removal (timing and extent) of the seasonal snowpack, which exposes lower-albedo firn and/or glacier ice, while melting glacier ice releases impurities that further reduce its albedo. Given that surface temperature and albedo are inextricably linked, knowing where and when albedo changes are likely to occur in future is important for predicting future rates of mass loss from the QEI ice caps. Recent investigations of atmospheric circulation patterns over the QEI (e.g. Gardner and Sharp, 2007) focused on characterization of July temperature and atmospheric conditions, since July is usually the month when melt rates peak. Our results suggest, however, that changes occurring during the month of August are also important, especially as the length of the melt season continues to increase.

Data availability. MODIS data are available from https://lpdaac. usgs.gov/ (Schaaf and Wang, 2015; Wan et al., 2015). NCEP Reanalysis data (Kalnay et al., 1996) were provided by the NOAA/OAR/ESRL PSD, Boulder, Colorado, USA, from their Web site at https://www.esrl.noaa.gov/psd/, accessed June 2017.

\section{The Supplement related to this article is available online at https://doi.org/10.5194/tc-12-701-2018-supplement.}

Competing interests. The authors declare that they have no conflict of interest.

Acknowledgements. We thank NSERC Canada (Discovery Grant to Martin Sharp, Vanier Canada Postgraduate Scholarship to Colleen A. Mortimer) and Alberta Innovates - Technology Futures (Martin Sharp) for financial support. Scott Williamson provided helpful advice on MODIS data processing, and Bert Wouters provided 2016 GRACE data. We thank two anonymous reviewers for their comments.

Edited by: Marco Tedesco

Reviewed by: two anonymous referees

\section{References}

Ackerman, S. A., Strabala, K. I., Menzel, P. W., Frey, R. A., Moeller, C. C., and Gumley, L. E.: Discriminating clear sky from clouds with MODIS, J. Geophys. Res., 103, 32141-32157, https://doi.org/10.1029/1998JD200032, 1998.

Alexander, P. M., Tedesco, M., Fettweis, X., van de Wal, R. S. W., Smeets, C. J. P. P., and van den Broeke, M. R.: Assessing spatiotemporal variability and trends in modelled and measured Greenland Ice Sheet albedo (2000-2013), The Cryosphere, 8, 22932312, https://doi.org/10.5194/tc-8-2293-2014, 2014.
Alt, B. T.: Synoptic climate controls of mass-balance variations on Devon Island Ice Cap, Arctic Alpine Res., 10, 61-80, https://doi.org/10.2307/1550657, 1978.

Alt, B. T.: Developing synoptic analogs for extreme mass balance conditions on Queen Elizabeth Island ice caps, J. Appl. Climate, 26, 1605-1623, https://doi.org/10.1175/15200450(1987)026<1605:DSAFEM>2.0.CO;2, 1987.

Arendt, A., Bolch, T., Cogley, J. G., Gardner, A., Hagen, J.-O., Hock, R., Kaser, G., Pfeffer, W. T., Moholdt, G., Paul, F., Radi?, V., Andreassen, L., Bajracharya, S., Beedle, M., Berthier, E., Bhambri, R., Bliss, A., Brown, I., Burgess, E., Burgess, D., Cawkwell, F., Chinn, T., Copland, L., Davies, B., Dolgova, E., Filbert, K., Forester, R., Fountain, A., Frey, H., Giffen, B., Glasser, N., Gurney, S., Hagg, W., Hall, D., Haritashya, U. K., Hartmann, G., Helm, C., Herreid, S., Howat, I., Kapustin, G., Khromova, T., Kienholz, C., Koenig, M., Kohler, J., Kriegel, D., Kutuzov, S., Lavrentiev, I., LeBris, R., Lund, J., Manley, W., Mayer, C., Li, X., Menounos, B., Mercer, A., Moelg, N., Mool, P., Nosenko, G., Negrete, A., Nuth, C., Pettersson, R., Racoviteanu, A., Ranzi, R., Rastner, P., Rau, F., Rich, J., Rott, H., Schneider, C., Seliverstov, Y., Sharp, M., Sigurðsson, O., Stokes, C., Wheate, R., Winsvold, S., Wolken, G., Wyatt, F., and Zheltyhina, N.: Randolph Glacier Inventory Vers. 3.0: a dataset of Global Glacier Outlines. Global Land Ice Measurements from Space, Boulder, CO, available at: https://www.glims.org/RGI/ rgi32_dl.html (last access: January 2016), 2012.

Barnes, W. L., Pagano, T. S., and Salomonson, V. V.: Prelaunch characteristics of the Moderate Resolution Imaging Spectroradiometer (MODIS) on EOS-AM1, IEEE T. Geosci. Remote, 36, 1088-1100, https://doi.org/10.1109/36.700993, 1998.

Bezeau, P., Sharp, M., and Gascon, G.: Variability in summer anticyclonic circulation over the Canadian Arctic Archipelago and west Greenland in the late 20th/early 21 st centuries and its effects on glacier mass balance, Int. J. Climatol., 35, 540-557, https://doi.org/10.1002/joc.4000, 2015.

Box, J. E., Fettweis, X., Stroeve, J. C., Tedesco, M., Hall, D. K., and Steffen, K.: Greenland ice sheet albedo feedback: thermodynamics and atmospheric drivers, The Cryosphere, 6, 821-839, https://doi.org/10.5194/tc-6-821-2012, 2012.

Box, J. E., van As, D., and Steffen, K.: Greenland, Canadian and Icelandic land ice albedo grids (2000-2016), Geol. Surv. Den. Greenl., 38, 69-72, 2017.

Braithwaite, R. J.: Mass balance characteristics of arctic glaciers, Ann. Glaciol., 42, 225-229, https://doi.org/10.3189/172756405781812899, 2005.

Casey, K. A., Polashenski, C. M., Chen, J., and Tedesco, M.: Impact of MODIS sensor calibration updates on Greenland Ice Sheet surface reflectance and albedo trends, The Cryosphere, 11, 17811795, https://doi.org/10.5194/tc-11-1781-2017, 2017.

Clarke, A. D. and Noone, K. J.: Soot in the Arctic snowpack: a cause for perturbations in radiative transfer, Atmos. Environ., 19, 2045-2053, https://doi.org/10.1016/0004-6981(85)90113-1, 1985.

Colbeck, S. C.: An overview of seasonal snow metamorphism, Rev. Geophys., 20, 45-61, https://doi.org/10.1029/RG020i001p00045, 1982.

Conway, H., Gades, A., and Raymond, C. F.: Albedo of dirty snow during conditions of melt, Water Resour. Res., 32, 1716-1718, https://doi.org/10.1029/96WR00712, 1996. 
Cuffey, K. M. and Paterson, W. (Eds.): The Physics of Glaciers, 4th edn., Butterworth-Heinemann, Oxford, 2010.

Doherty, S. J., Warren, S. G., Grenfell, T. C., Clarke, A. D., and Brandt, R. E.: Light-absorbing impurities in Arctic snow, Atmos. Chem. Phys., 10, 11647-11680, https://doi.org/10.5194/acp-1011647-2010, 2010.

Flanner, M. G., Zender, C. S., Randerson, J. T., and Rasch, P. J.: Present-day climate forcing and response from black carbon in snow, J. Geophys. Res., 112, D11202, https://doi.org/10.1029/2006JD008003, 2007.

Fountain, A. G., Tranter, M., Nylen, T. H., and Muller, D. R.: Evolution of cryoconite holes and their contribution to meltwater runoff from glaciers in the McMurdo Dry Valleys, Antarctica, J. Glaciol., 50, 35-45, https://doi.org/10.3189/172756504781830312, 2004.

Franz, B. A., Kwiatkowska, E. J., Meister, G., and McClain, C. R.: Moderate Resolution Imaging Spectroradiometer on Terra: limitations for ocean color applications, J. Appl. Remote Sens., 2, 023525, https://doi.org/10.1117/1.2957964, 2008.

Gardner, A. S. and Sharp, M.: Influence of the Arctic circumpolar vortex on the mass balance of Canadian High Arctic glaciers, J. Climate, 20, 4586-4598, https://doi.org/10.1175/JCLI4268.1, 2007.

Gardner, A. S., Moholdt, G., Wouters, B., Wolken, G. J., Burgess, D. O., Sharp, M. J., Braun, C., and Labine, C.: Sharply increased mass loss from glaciers and ice caps in the Canadian Arctic Archipelago, Nature, 473, 357-360, https://doi.org/10.1038/nature10089, 2011.

Gardner, A. S., Moholdt, G., Cogley, G., Wouters, B., Arendt, A. A., Wahr, J., Berthier, E., Hock, R., Pfeffer, W. T., Kaser, G., Ligtenberg, S. R. M., Bolch, T., Sharp, M., Hagen, J. O., van den Broeke, M. R., and Paul, F.: A reconciled estimate of glacier contributions to sea level rise: 2003 to 2009 , Science, 340, 852857, https://doi.org/10.1126/science.1234532, 2013.

Gascon, G., Sharp, M., and Bush, A.: Changes in melt season characteristics on Devon Ice Cap, Canada, and their association with the Arctic atmospheric circulation, Ann. Glaciol., 54, 101-110, https://doi.org/10.3189/2013AoG63A601, 2013.

Guenther, B., Barnes, W., Knight, E., Barker, J., Harnden, J., Weber, R., Roberto, M., Godden, G., Montgomery, H., and Abel, P.: MODIS calibration: a brief review of the strategy for the at-launch calibration approach, J. Atmos. Ocean. Tech., 13, 274-285, https://doi.org/10.1175/15200426(1996)013<0274:MCABRO>2.0.CO;2, 1996.

Guenther, B. Godden, G. D., Xiong, X., Knight, E. J., Qiu, S. Y., Montgomery, H., Hopkins, M. M., Khayat, M. G., and Zhidong Hao, Z.: Prelaunch algorithm and data format for the Level 1 calibration products for the EOS-AM1 Moderate Resolution Imaging Spectroradiometer (MODIS), IEEE T. Geosci. Remote, 36, 1142-1151, https://doi.org/10.1109/36.701021, 1998.

Hall, D. K., Riggs, G. A., Salomonson, V. V., DiGirolamo, N. E., Bayr, K. J.: MODIS snow-cover products, Remote Sens. Environ., 83, 181-194, https://doi.org/10.1016/S00344257(02)00095-0, 2002.

Hall, D. K., Box, J. E., Casey, K. A., Hook, S. J., Shuman, C. A., and Steffen, K.: Comparison of satellite-derived and in-situ observations of ice and snow surface temperatures over Greenland, Remote Sens. Environ., 112, 3739-3749, https://doi.org/10.1016/j.rse.2008.05.007, 2008a.
Hall, D. K., Williams, R. S., Luthcke, S. B., and DiGirolamo, N. E.: Greenland ice sheet surface temperature, melt and mass loss: 2000-2006, J. Glaciol., 54, 81-93, https://doi.org/10.3189/002214308784409170, 2008 b.

Hall, D. K., Comiso, J. C., DiGirolamo, N. E., Shuman, C. A., Key, J. R., and Koenig, L. S.: A satellite-derived climatequality data record of the clear-sky surface temperature of the Greenland ice sheet, J. Climate, 25, 4785-4798, https://doi.org/10.1175/JCLI-D-11-00365.1, 2012.

He, T., Lian, S. L., and Song, D. X.: Analysis of global land surface albedo climatology and spatial-temporal variation during 19812010 from multiple satellite products, J. Geophys. Res.-Atmos., 119, 10281-10298, https://doi.org/10.1002/2014DJ021667, 2014.

Jin, Y., Schaaf, C. B., Woodcock, C. E., Gao, F., Li, X., and Strahler, A. H.: Consistency of MODIS surface BRDF/Albedo retrievals: 1. Algorithm performance, J. Geophys. Res., 108, 4158, https://doi.org/10.1029/2002JD002803, 2003.

Justice, C. O., Vermote, E., Townshend, J. R. G., Defries, R., Roy, D. P., Hall, D. K., Vincent, V., Salomonson, V. V., Privette, J. L., Riggs, G., Strahler, A., Lutch, W., Myneni, R. B., Knyazikhin, Y., Running, S. W., Nemani, R. R., Wan, Z., Huete, A. R., van Leeuwen, W., Wolfe, R. E., Giglio, L., Muller, J. Lewis, P., and Barnsley, M. J.: The Moderate Resolution Imaging Spectroradiometer (MODIS): land remote sensing for global change research, IEEE T. Geosci. Remote, 36, 1228 1249, https://doi.org/10.1109/36.701075, 1998.

Kalnay, E., Kanamitsu, M., Kistler, R., Collins, W., Deaven, D., Gandin, L., Iredell, M., Saha, S., White, G., Woollen, J., Zhu, Y., Leetmaa, A., Reynolds, R., Chelliah, M., Ebisuzaki, W., Higgins, W., Janowiak, J., Mo, K. C., Ropelewski, C., Wang, J., Jenne, R., and Joseph, D.: The NCEP/NCAR 40 year reanalysis project, B. Am. Meteorol. Soc., 77, 437-471, https://doi.org/10.1175/15200477(1996)077<0437:TNYRP>2.0.CO;2, 1996.

Koenig, L. S. and Hall, D. K.: Comparison of satellite, thermochron and station temperatures at Summit, Greenland, during the winter of 2008/09, J. Glaciol., 56, 735-741, https://doi.org/10.3189/002214310793146269, 2010.

Koerner, R. M.: Devon Island ice cap: core stratigraphy and paleoclimate, Science, 196, 15-18, https://doi.org/10.1126/science.196.4285.15, 1977.

Koerner, R. M.: Accumulation, ablation, and oxygen isotope variations on the Queen Elizabeth Islands ice caps, Canada, J. Glaciol., 22, 25-41, 1979.

Koerner, R. M.: Mass balance of glaciers in the Queen Elizabeth Islands, Nunavut, Canada, Ann. Glaciol., 42, 417-423, https://doi.org/10.3189/172756405781813122, 2005.

Kwiatkowska, E. J., Franz, B. A., Meister, G., McClain, C. R., and Xiong, X.: Cross calibration of ocean-color bands from Moderate-Resolution Imaging Spectroradiometer on Terra platform, Appl. Optics, 47, 6796-6810, https://doi.org/10.1364/AO.47.006796, 2008.

Lenaerts, J. T. M., van Angelen, J. H., van den Broeke, M. R., Gardner, A. S., Wouters, B., and van Meijgaard, E.: Irreversible mass loss of Canadian Arctic Archipelago glaciers, Geophys. Res. Lett., 40, 870-874, https://doi.org/10.1002/grl.50214, 2013.

Liu, J., Schaaf, C. B., Strahler, A. H., Jiao, Z., Shuai, Y., Zhang, Q., Román, M., Augustine, J. A., and Dutton, E. G.: 
Validation of Moderate Resolution Imaging Spectroradiometer (MODIS) albedo retrieval algorithm: dependence of albedo on solar zenith angle, J. Geophys. Res.-Atmos., 114, D01106, https://doi.org/10.1029/2008JD009969, 2009.

Lucht, W., Schaaf, C. B., and Strahler, A. H.: An algorithm for the retrieval of albedo from space using semiempirical BRDF models, IEEE T. Geosci. Remote, 38, 977-998, 2000.

Lyapustin, A., Wang, Y., Xiong, X., Meister, G., Platnick, S., Levy, R., Franz, B., Korkin, S., Hilker, T., Tucker, J., Hall, F., Sellers, P., Wu, A., and Angal, A.: Scientific impact of MODIS C5 calibration degradation and C6+ improvements, Atmos. Meas. Tech., 7, 4353-4365, https://doi.org/10.5194/amt-7-4353-2014, 2014.

Mortimer, C. A., Sharp, M., and Wouters, B.: Glacier surface temperatures in the Canadian high arctic, 2000-2015, J. Glaciol., 62, 963-975, https://doi.org/10.1017/jog.2016.80, 2016.

Pan, C., Xiong, X., and Che, N.: MODIS pre-launch characterization of reflective solar bands response vs. Scan angle, Proc. SPIE - Earth Observeing Systems XII, Opt. Eng. Applications, 66770R, https://doi.org/10.1117/12.730573, 2007.

Pfeffer, W. T., Arendt, A. A., Bliss, A., Bloch, T., Cogley, J. G., Gardner, A. S., Hagen, J. O., Hock, R., Kaser, G., Kienholz, C., Miles, E. S., Moholtd, G., Molg, N., Paul, F., Radic, V., Rastner, P., Raup, B., Rich, J., Sharp, M. J., and The Randolph Consortium: The Randolph Glacier Inventory: a globally complete inventory of glaciers, J. Glaciol., 60, 537-552, https://doi.org/10.3189/2014JoG13J176, 2014.

Rajewicz, J. and Marshall, S. J.: Variability and trends in anticyclonic circulation over the Greenland ice sheet, 1948-2013, Geophys. Res. Lett., 41, 2842-2850, https://doi.org/10.1002/2014GL059255, 2014.

Salomon, J. G., Schaaf, C. B., Strahler, A. H., Gao, F., and Jin, Y.: Validation of the MODIS Bidirectional Reflectance Distribution Function and Albedo retrievals using combined observations from the Aqua and Terra platforms, IEEE T. Geosci. Remote, 44, 1555-1565, 2006.

Schaaf, C. B., Gao, F., Strahler, A. H., Lucht, W., Li, X., Tsang, T., Strugnell, N. C., Zhang, X., Jin, Y., Muller, J. P., Lewis, P., Barnsley, M., Hobson, P., Disney, M., Roberts, G., Dunderdale, M., Doll, C., d'Entremont, R. P., Hu, B., Liang, S., Privette, J. L., and Roy, D.: First operational BRDF, albedo nadir reflectance products from MODIS, Remote Sens. Environ., 83, 135-148, https://doi.org/10.1016/S0034-4257(02)00091-3, 2002.

Schaaf, C. B., Wang, Z., and Strahler, A. H.: Commentary on Wang and Zender - MODIS snow albedo bias at high solar zenith angles relative to theory and in situ observations in Greenland, Remote Sens. Environ., 115, 1296-1300, https://doi.org/10.1016/j.rse.2011.01.002, 2011.

Schaaf, C. and Wang, Z.: MCD43A3 MODIS/Terra +Aqua BRDF/Albedo Daily L3 Global - $500 \mathrm{~m}$ V006, NASA EOSDIS Land Processes DAA C, available at: http://lpdaac.usgs.gov/ (last access: November 2016), https://doi.org/10.5067/MODIS/MCD43A3.006, 2015.

Sharp, M., Burgess, D. O., Cogley, J. G., Ecclestone, M., Labine, C., and Wolken, G. J.: Extreme melt on Canada's Arctic ice caps in the 21st century, Geophys. Res. Lett., 38, L11501, https://doi.org/10.1029/2011GL047381, 2011.

Stroeve, J. C., Box, J., Gao, F., Liang, S., Nolin, A., and Schaaf, C.: Accuracy assessment of the MODIS 16day albedo product for snow: comparison with Greenland in situ measurements, Remote Sens. Environ., 94, 46-60, https://doi.org/10.1016/j.rse.2004.09.001, 2005.

Stroeve, J. C., Box, J., and Haran, T.: Evaluation of the MODIS (MOD10A1) daily snow albedo product over the Greenland Ice Sheet, Remote Sens. Environ., 105, 155-171, https://doi.org/10.1016/j.rse.2006.06.009, 2006.

Stroeve, J., Box, J. E., Wang, Z., Schaaf, C., and Barret, A.: Re-evaluation of MODIS MCD43 Greenland albedo accuracy and trends, Remote Sens. Environ., 138, 199-214, https://doi.org/10.1016/j.rse.2013.07.023, 2013.

Strugnell, N. and Lucht, W.: Continental-scale albedo inferred from AVHRR data, land cover class and field observations of typical BRDFs, J. Climate, 14, 1360-1376, https://doi.org/10.1175/15200442(2001)014<1360:AATICS>2.0.CO;2, 2001.

Sun, J., Xiong, X., Guenther, B., and Barnes, W.: Radiometric stability monitoring of the MODIS reflective solar bands using the Moon, Metrologia, 40, S85, https://doi.org/10.1088/00261394/40/1/319, 2003.

Sun, J., Xiong, X., Angal, A., Chen, H., Wu, A., and Geng, X.: Time-dependent response vs. scan angle for MODIS reflective solar bands, IEEE T. Geosci. Remote, 52, 3159-3174, https://doi.org/10.1109/TGRS.2013.2271448, 2014.

Tedesco, M., Doherty, S., Fettweis, X., Alexander, P., Jeyaratnam, J., and Stroeve, J.: The darkening of the Greenland ice sheet: trends, drivers, and projections (1981-2100), The Cryosphere, 10, 477-496, https://doi.org/10.5194/tc-10-477-2016, 2016.

Toller, G., Xiong, X., Sun, J., Wenny, B. N., Geng, X., Kuyper, J., Angal, A., Chen, H., Madhavan, S., and Wu, A.: Terra and Aqua moderate-resolution imaging spectroradiometer collection 6 level 1B algorithm, J. Appl. Remote Sens., 7, 073557-073557, https://doi.org/10.1117/1.JRS.7.073557, 2013.

van den Broeke, M. R., Smeets, C. J. P. P., and van de Wal, R. S. W.: The seasonal cycle and interannual variability of surface energy balance and melt in the ablation zone of the west Greenland ice sheet, The Cryosphere, 5, 377-390, https://doi.org/10.5194/tc-5377-2011, 2011.

Vermote, E. F., Kotchenova, S. Y., and Ray, J. P.: MODIS surface reflectance user's guide, MODIS Land Surface Reflectance Science Computing Facility, version 1, Greenbelt MD, 2011.

Vincent, L. A., Zhang, X., Brown, R. D., Feng, Y., Mekis, E., Milewska, E. J., Wan, H., and Wang, X. L.: Observed trends in Canada's climate and influence of low-frequency variability modes, J. Climate, 28, 4545-4560, https://doi.org/10.1175/JCLID-14-00697.1, 2015.

Wan, Z. and Li, Z. L.: A physics-based algorithm for retrieving land-surface emissivity and temperature from EOS/MODIS data, IEEE T. Geosci. Remote, 35, 980-996, 1997.

Wan, Z., Zhang, Y., Zhang, Q., and Li, Z. L.: Validation of the land-surface temperature products retrieved from Terra Moderate Resolution Spectroradiomerter data, Remote Sens. Environ., 83, 163-180, https://doi.org/10.1016/S0034-4257(02)00093-7, 2002.

Wan, Z., Hook, S., and Hulley, G.: MOD11A2 MODIS/Terra Land Surface Temperature and the Emissivity 8Day L3 Global $1 \mathrm{~km}$ SIN Grid, NASA LP DAAC, https://doi.org/10.5067/MODIS/MOD11A2.006, 2015.

Wang, Z., Schaaf, C. B., Chopping, M. J., Strahler, A. H., Wang, J., Román, M. O., Rocha, A. V., Woodcock, C. E., 
and Shuai, Y.: Evaluation of Moderate-resolution Imaging Spectroradiometer (MODIS) snow albedo product (MCD43A) over tundra, Remote Sens. Environ., 117, 264280, https://doi.org/10.1016/j.rse.2011.10.002, 2012.

Wanner, W., Strahler, A. H., Hu, B., Lewis, P., Muller, J. P., Li, X., Schaaf, C. L. B., and Barnsley, M. J.: Global retrieval of bidirectional reflectance and albedo over than from EOS MODIS and MISR data: theory and algorithm, J. Geophys. Res., 102, 1714317162, https://doi.org/10.1029/96JD03295, 1997.

Warren, S. G.: Optical properties of snow, Rev. Geophys., 20, 6789, https://doi.org/10.1029/RG020i001p00067, 1982.

Warren, S. G. and Wiscombe, W. J.: A model for the spectral albedo of snow. II Snow containing atmospheric aerosols, J. Atmos. Sci., 37, 2734-2745, 1980.

Wenny, B. N., Sun, J., Xiong, X., Wu, A., Chen, H., Angal, A., Choi, T., Madhavan, S., Geng, X., Kuyper, J., and Tan, L.: MODIS calibration algorithm improvements developed for Collection 6 Level-1B, Proc. SPIE, 78071F, https://doi.org/10.1117/12.860892, 2010.
Wiscombe, W. J. and Warren, S. G.: A model for the spectral albedo of snow. I: Pure snow, J. Atmos. Sci., 37, 2712-2732, 1980.

Wolken, G., Sharp, M., Andreassen, L. M., Arendt, A., Burgess, D., Cogley, J. G., Copland, L., Kohler, J., O’Neel, S., Pelto, M., Thomson, L., and Wouters, B.: [Arctic] Glaciers and ice caps outside Greenland [in "State of the Climate 2015"], B. Am. Meteorol. Soc., 97, S142-S145, 2016.

Xiong, X., Esposito, J., Sun, J., Pan, C., Guenther, B., and Barnes, W. L.: Degradation of MODIS optics and its reflective solar bands calibration, Proc. SPIE, 4540, 62-70, https://doi.org/10.1117/12.450646, 2001.

Xiong, X., Eriyes, H., Xiong, S., Xie, X., Esposito, J., Sun, J., and Barnes, W.: Performance of Terra MODIS solar diffuser and solar diffuser stability monitor, Proc. SPIE, 58820S, https://doi.org/10.1117/12.615334, 2005.

Xiong, X. and Barnes, W.: An overview of MODIS radiometric calibration and characterization, Adv. Atmos. Sci., 23, 69-79, https://doi.org/10.1007/s00376-006-0008-3, 2006. 